\title{
Mantle earthquakes in the Crimea-Black Sea-Caucasus regions
}

\author{
V. Burmin ${ }^{1}$, O. Kendzera ${ }^{2}$, L. Shumlianska ${ }^{2}$, T. Amashukeli ${ }^{2}, 2021$ \\ ${ }^{1} \mathrm{O}$. Yu. Schmidt Institute of Physics of the Earth \\ of the Russian Academy of Sciences, Moscow, Russia \\ ${ }^{2}$ S. I. Subbotin Institute of Geophysics of the National Academy \\ of Sciences of Ukraine, Kiev, Ukraine \\ Received 5 January 2021
}

\begin{abstract}
The question of the existence of foci of deep earthquakes in the region of the CrimeaBlack Sea-Caucasus is extremely important from the point of view of the geodynamics of the region. Previously it was thought that only crustal earthquakes could occur in this region. Recently, results have been obtained that show that earthquakes with depths of at least $300 \mathrm{~km}$ occur in this region.

The article discusses the question of how plausible these results are and why they were not obtained earlier. Seven specific examples of the ambiguous determination of the depth of earthquake hypocenters in the Crimea-Black Sea-Caucasus region are considered. These examples clearly show that determining the coordinates of earthquake hypocenters using algorithms based on the Geiger method does not allow one to uniquely determine the depth of the hypocenters. The article gives an idea of the authors about the origin of mantle earthquakes in the Caucasian and Crimean-Black Sea regions. For the Caucasus region, mantle earthquakes are associated with two reasons: submersion of the lithospheric layer; in the asthenospheric layer, represented in the seismotomographic sections by a low-velocity anomaly, the nature of earthquake foci is associated with fluids formed during phase transition reactions. In the Crimean-Black Sea region, earthquake foci are located in the lithosphere layer, and the sliding of the lithosphere along the less viscous underlying layer of the upper mantle causes tectonic movements in the lithosphere accompanied by earthquakes. In addition, to determine the coordinates of the hypocenters of the Crimean and Caucasian earthquakes during routine processing, hodographs were used for depths not exceeding $35 \mathrm{~km}$ for the Crimea and $50 \mathrm{~km}$ for the Caucasus and 150 for the North Caucasus. This circumstance is the main reason why deep earthquakes could not be detected.
\end{abstract}

Key words: hypocenters, earthquakes, travel-time curves, seismic waves.

Introduction. The question of the existence of deep earthquake foci in the Crimea-Black Sea-Caucasus region is extremely important for the region's geodynamics. It was believed that, in the Crimean-Black Sea region, only crustal earthquakes occur, and in the Caucasus region mantle earthquakes to depths of $150 \mathrm{~km}$ are located only in the northeastern part of it. However, in the Black Sea and Caucasus regions the depths of foci can reach 300 km [Burmin, Shumlianska, 2015; 2018a, b; Burmin et al., 2019] (Fig. 1-4).

According to [Burmin, Shumlianska,
2015], determining depths of the hypocenters of earthquakes by traditional methods produces large errors. The papers [Lebedeva, 1958; Godzikovskaya, 1988; Gozikovskaya, Reisner, 1989; Burmin, Shumlianska, 2015, $2018 \mathrm{~b}$ ] discuss the problem of the validity of such estimates, in particular for deep earthquakes.

The Crimean Seismology Bulletin contains about 1,650 events recorded in the CrimeaBlack Sea region in 1970-2015. Out of these, about 170 events had a depth of more than $60 \mathrm{~km}$. 


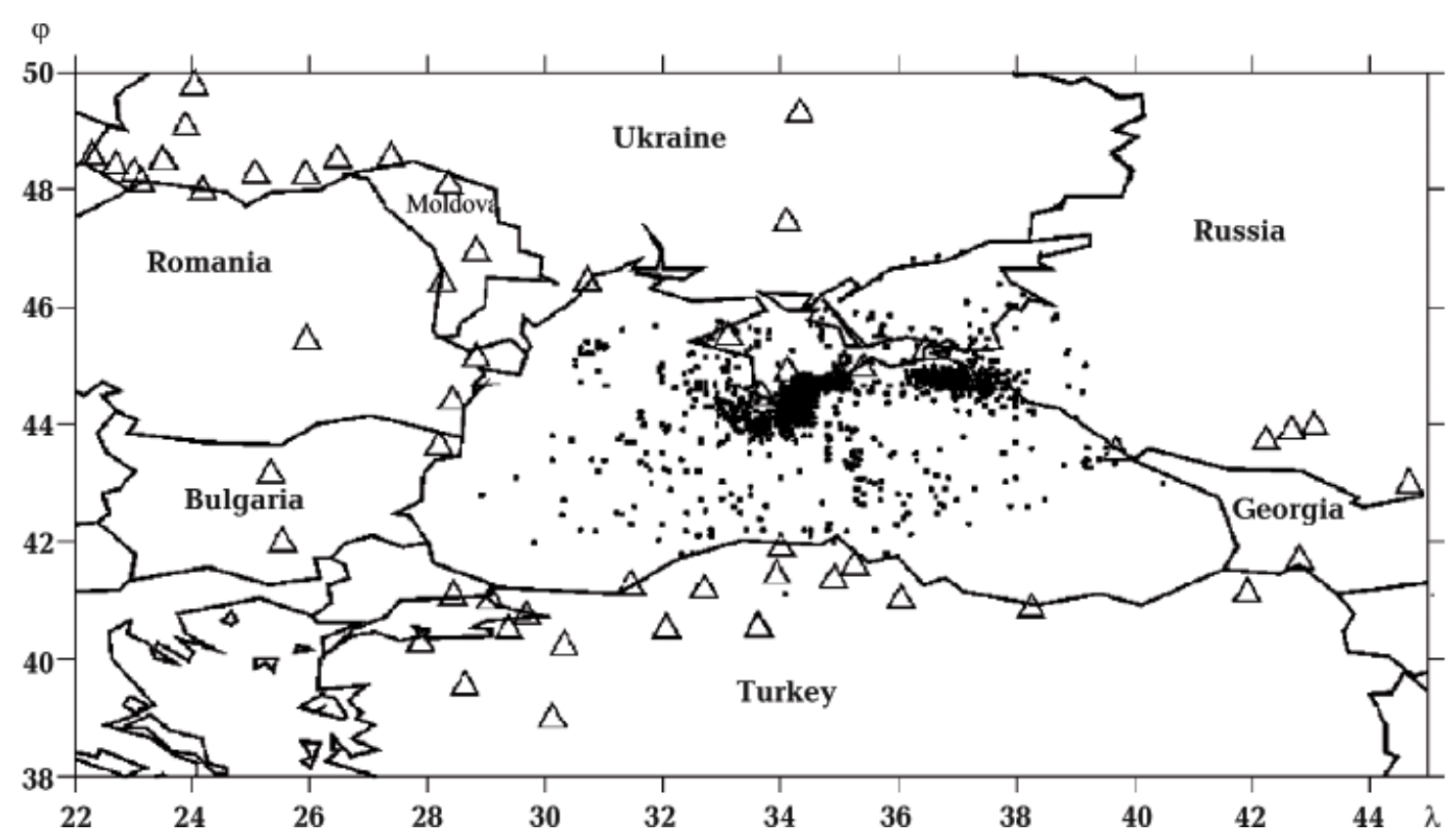

Fig. 1. The distribution of epicenters in the Crimean-Black Sea region.

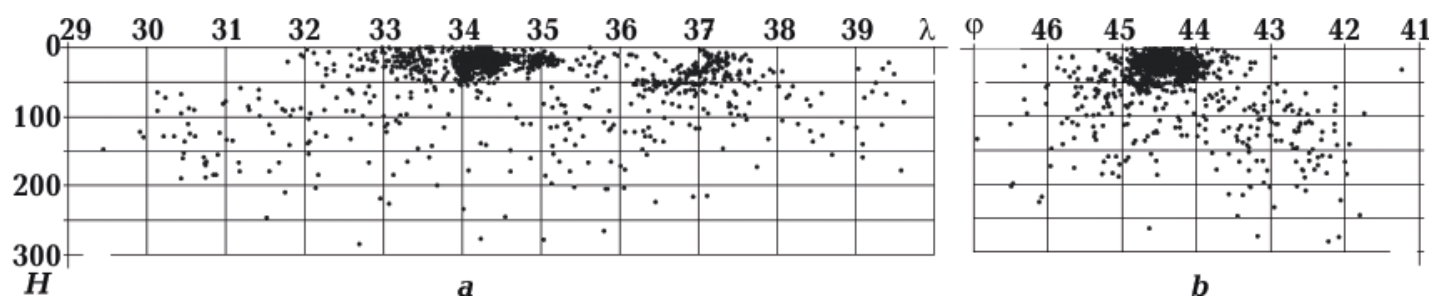

Fig. 2. Distribution of hypocenters in the longitudinal (a) and latitudinal (b) directions in the Crimean-Black Sea region.

The Caucasus bulletins for 1971-2015 show the arrival times of seismic waves for $\sim 14,400$ earthquakes, recorded by three or more stations. Of these, about 1,350 events were located at depths from 50 to $150 \mathrm{~km}$ and 270 events had depths from 150 to $300 \mathrm{~km}$.

In this paper, we point to the reasons why the deep earthquakes of the Crimea-Black SeaCaucasus region were identified as crustal.

Geological and tectonic setting in the Caucasian and Crimean-Black Sea regions. The Caucasus is one of the geodynamically active regions of the Alpine-Himalayan belt. It forms an elongated mountain system between the Black and Caspian Seas with a total length of more than $1,300 \mathrm{~km}$. The features of the region's geodynamics are due to the interaction of two large lithospheric plates - the
Eurasian and Arabian. The region is a typical example of collisional tectonics characterized by compressional deformation in the submeridional direction, extension in the sublatitudinal direction, and general uplift of the Greater Caucasus mountain system. It is characterized by the presence of active seismogenic faults. Young volcanoes are also developed in the central part of the folded structure, the largest of which, Elbrus and Kazbek, are in the immediate vicinity of the Main ridge of the Caucasus [Khain, 1975].

The modern geological structure of the Caucasus was formed during a complex multistage (long-term stepwise) evolution of the lithosphere. In the Paleozoic-Cenozoic, the formation of the main geological complexes in this area was associated with the evolution 


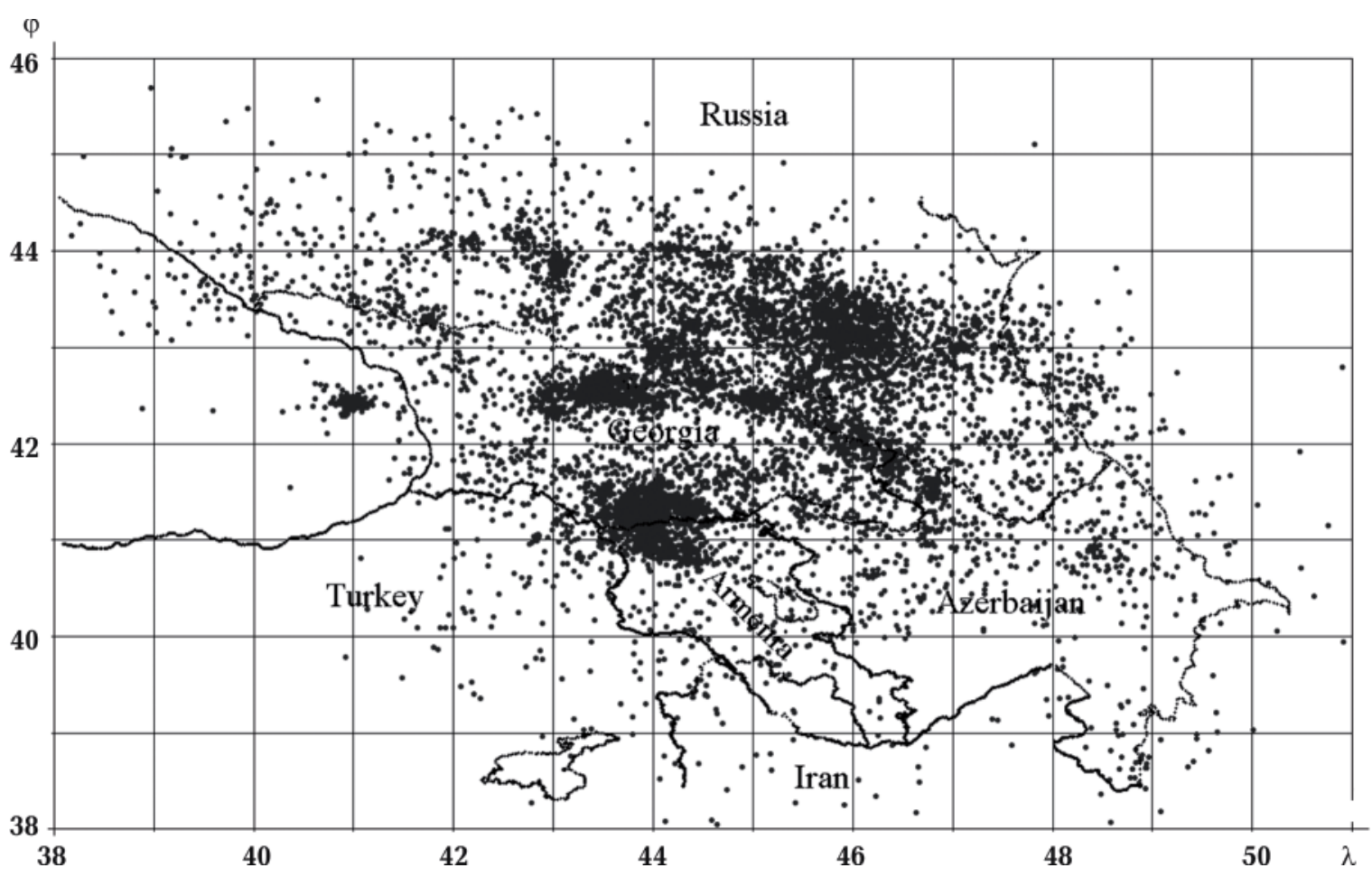

Fig. 3. The distribution of epicenters in the Caucasus.
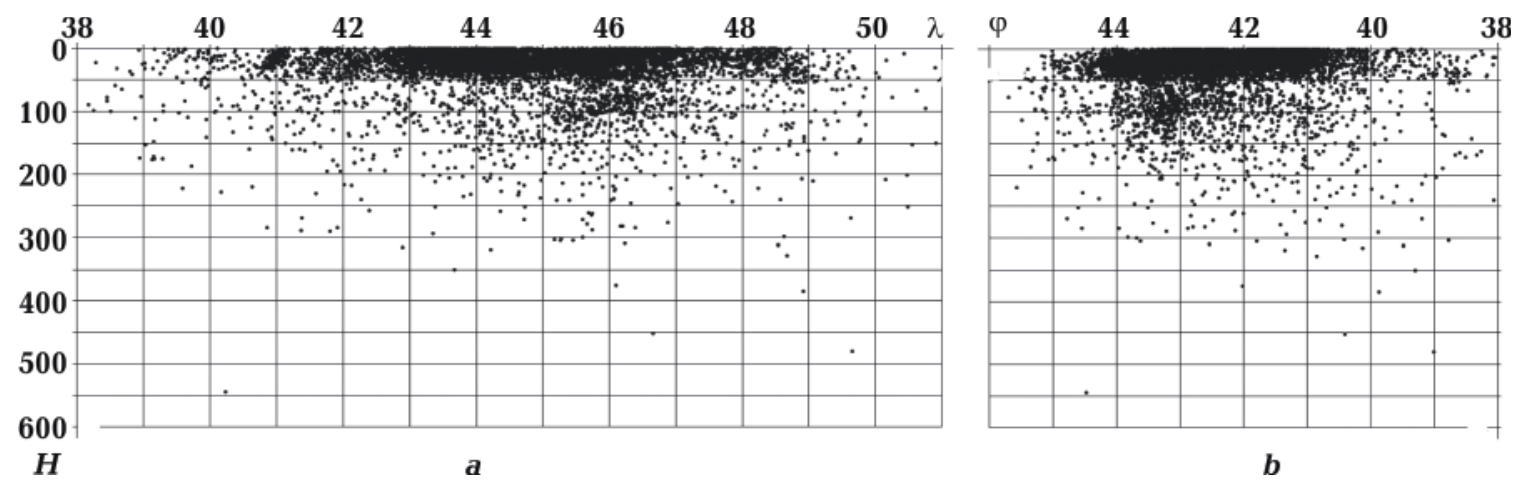

Fig. 4. Distribution of hypocenters in the longitudinal $(a)$ and latitudinal $(b)$ directions in the Caucasus.

of the Paleotethis Ocean located between Gondwana and Eurasia [Adamia et al., 2011a]. The Gondwana complexes are mainly identified as part of the passive continental margins, while the Eurasian blocks are associated with arc volcanogenic complexes and sedimentary series, indicating the presence of subduction zones, which were closed in stages with a shift to the south [Khain, 1975].

It is assumed that there were two subduction zones in the Early and Middle Paleozoic. One of them was submerged under the axial zones of the foredeeps, the other was located along the southern boundary of the Peredo- voy Range of the Caucasus. In the Late Paleozoic, subduction zones were traced along the thrust fault of the Main Caucasian ridge and on the southern slope of the Greater Caucasus, in the Neogene-Quaternary period along the southern slope of the Greater Caucasus and along the Vedian ophiolite suture [Koronovskiy, 1997].

In the Cenozoic, the tectonic structure of the Caucasus as part of the mobile Alpine-Himalayan belt was formed by the near-meridional convergence of the Arabian lithospheric plate and the adjacent margin of the East European part of the Eurasian plate, followed by 
deformation of the latter, which is associated with the closure of the Tethys Ocean [Khain, 1975; Adamia et al., 2011a]. The last collision of the Arabian and Eurasian plates happened in the Neogene [Adamia et al., 2011b]. As a result of these horizontal displacements, the Caucasian segment of the Alpine-Himalayan mobile belt was deformed, layers of sedimentary and volcanic rocks crumpled into folds, base blocks experienced multidirectional displacements, and the upper crustal horizons were disturbed by uplifts and thrusts. The convergence of these plates was established by GPS measurements; the current rate of convergence is $1-2.5 \mathrm{~mm} /$ year [McClusky et al., 2000; Reilinger et al., 2006].

Intense faulting tectonics, as well as flexure-like bends, significantly complicate the arch deformations, due to which the vaults are mosaic structures connected by means of the latest faults or flexures. At the same time, the largest and deepest of them reflect the movement of the upper mantle and the lower part of the crust, and the less deep ones are associated with the reaction of the crystalline crust to the bends of deeper zones. Milanovsky [1991] emphasizes the importance of faults, mainly transverse, in the seismicity of the Caucasus, especially in the zone of the Transcaucasian uplift, and connects seismic phenomena with the most active, youngest neotectonic structures and high gradients of vertical movements.

In addition to establishing correlations between the recent volcanism of the Caucasus and uplifts that occurred under extension conditions and the resulting steep faults and cracks, it is especially important to identify the «dome» and "crust» types of volcanism in this area. The fact is that the formation of magma chambers was associated with the formation of huge vaults, covering not only the earth's crust, but also the upper mantle. The deformation of the earth's crust affects the intensity and nature of the latest tectonic movements. The cause of these movements is the deformation of the upper mantle due to the influx of matter in the zones of uplifts and deep compression and its outflow from the zones of subsidence and extension.
The tectonic setting of the Black SeaCrimean region, as well as the Caucasian one, is created by deformation processes as a result of the northern drift of the Arabian plate. Within the Crimean active margin of the Black Sea, tectonic interaction is associated with different kinematics of the West and East Black Sea microplates. The East Black Sea microplate directly takes on the impulse of the Arabian plate and transfers it to the outskirts of the Scythian plate (the active margin of the East European platform). The nature of their interaction corresponds to the initial stage of convergence (microcollision), which implies mutual wedging of the plates during compression and initiation of obduction. The western block of the Crimean Mountains has independent activity due to the supposed mantle upwelling, which stimulates the rise and expansion of the orogen and its creeping into the West Black Sea depression [Gonchar, 2003].

Method. In seismological practice, various algorithms based on the Geiger method [Geiger, 1910, 1912] are used to determine the coordinates of earthquakes, according to which the functional of the residuals of time is minimized

$$
S_{t}=\sum_{i=1}^{n}\left(t_{i}-\tilde{t}_{i}\right)^{2}
$$

where $t_{i}$ is the theoretical arrival time of the seismic waves; $\tilde{t}_{i}$ - the observed arrival time of the seismic wave.

In this paper, to redefine the coordinates of the hypocenters of the Crimean-Black Sea earthquakes, we used a different algorithm based on minimizing the functional square of the distance difference between the «true» and the theoretical hypocenter

$$
S_{t}=\sum_{i=1}^{n}\left(D_{i}-d_{i}\right)^{2}+(H-h)^{2}
$$

where $D_{i}=\sqrt{X_{i}^{2}+Y_{i}^{2}}$ - epicentral distances and $H$ - the depth of earthquake; $d_{i}$ and $h$ - the same values, but corresponding to the true position of the hypocenter [Burmin, 1992]. $X_{i^{\prime}} Y_{i}$ and $H$ are determined by solving a system of nonlinear equations 


$$
\begin{gathered}
\left(X-x_{i}\right)^{2}+\left(Y-y_{i}\right)^{2}+H^{2}= \\
=v^{2}{ }_{i}\left(t_{i}-t_{0}\right)^{2}=d^{2}{ }_{i}+h^{2},
\end{gathered}
$$

where $X, Y, H$ and $t_{0}$ are hypocenter coordinates and time of earthquake (origin time); $x_{\mathrm{i}}, y_{\mathrm{i}}, t_{\mathrm{i}}$ are the coordinates of seismic stations recording the earthquake and the times of seismic waves arrival at these stations $(i=\overline{1, n})$; $v_{\mathrm{i}}$ - are the effective velocities of seismic waves propagation, numerically equal to the ratio between the distance from the $i$-th station to the hypocenter along a straight line and the travel time along the ray.

In the papers [Burmin, 1992; Burmin, Shumlianska, 2015] an algorithm for solving this problem is described in detail. In those articles it is shown that the problem (2), (3) gives a more stable solution than the problem (1). For implementing the algorithm, a program was written in FORTRAN98. The program uses the arrival times of both compression and shear waves. The time of occurrence of an earthquake is determined by the Wadati curve.

For the earthquakes, the experimental travel-time curves were constructed in the following way. The times of arrival of $P$-waves at the station were taken from the bulletins. The travel times of longitudinal seismic waves were determined as the difference between the arrival times of waves at the station and the times of occurrence of earthquakes. Time in the focus and the coordinates of the epicenters was taken from the catalogs. Epicentral distances were determined by solving the inverse geodesic problem by the coordinates of epicenters and seismic stations. From the obtained seismic wave travel times and epicentral distances, the points of travel time curves were constructed.

Let in the initial equation (3) variables $X, Y$ and $H$ are the unknowns. Then, introducing the new variable $x=X^{2}+Y^{2}+H^{2}$ and grouping the terms we have a system of equations

$$
X x_{i}+Y y_{i}-0.5 x=f_{i} \text {, }
$$

where $i=1,2, \ldots, n^{3} 3$;

$$
f_{i}=-0.5\left[v^{2}{ }_{i}\left(t^{2}{ }_{i}-t^{2}{ }_{0}\right)-\left(x^{2}{ }_{i}+y_{i}^{2}\right)\right] .
$$

System (4) is a system of linear algebraic equations in relation to the unknown parameters $X, Y$ and $x$. Here $X, Y$ and $x$ are independent variables.

We will write down systems of linear equations, relating hypocenter coordinates, velocity of seismic waves propagation and origin time in the matrix form

$$
\mathbf{K p}=\mathbf{f},
$$

where $\mathbf{K}=\left\{k_{i j}\right\}$ is the matrix of the system, representing mathematical model of the examined dependence; $\mathbf{p}^{\mathrm{T}}=\left\{p_{j}\right\}$ is the vectorcolumn of the searched parameters; $\mathbf{f}^{\mathrm{T}}=\left\{f_{i}\right\}$ is the vector-column of the quantities under observation; $i=1,2, \ldots, n ; j=1,2, \ldots, m ; n^{3} m$.

Let us find error estimates in determining the variances of vector $\mathbf{p}$ in equation (5) [Burmin, 1986].

Let the vector of free terms $\mathbf{f}$ and matrix $\mathbf{K}$ in (5) be set with errors D $\mathbf{f}^{1} 0$ and $D K^{1} 0$. In this case for the error of vector $\mathbf{p}$ equation hold

$$
\tilde{\mathbf{K}} \Delta \mathbf{p}=\Delta \mathbf{f}-\Delta \mathbf{K} \mathbf{p} .
$$

The solution of the equation will be calculated by the least squares method

$$
\Delta \mathbf{p}=\tilde{\mathbf{K}}^{+}(\Delta \mathbf{f}-\Delta \mathbf{K} \mathbf{p}) .
$$

The following relations are true for the errors of the components $\Delta p_{j}$ of vector $\mathbf{p}$

$$
\Delta p_{j}=\tilde{\mathbf{k}}_{j}^{(+)}(\Delta \mathbf{f}-\Delta \mathbf{K} \mathbf{p}), j=1,2, \ldots, m,
$$

where $\tilde{\mathbf{k}}_{j}^{(+)}$is a row vector of $\tilde{\mathbf{K}}^{+}$.

The Cauchy-Bunyakovsky inequality is used to derive a majorizing estimate of the $\Delta p_{j}$

$$
\left|\Delta p_{j}\right|=\left|\tilde{k}_{\mathbf{j}}^{(+)}(\Delta \mathbf{f}-\Delta \mathbf{K} \mathbf{p})\right|<\left\|\tilde{k}_{j}^{(+)}\right\|\|\Delta \mathbf{f}-\Delta \mathbf{K} \mathbf{p}\|,
$$

where $\|\bullet\|$ is the Euclidean norm.

For the error of the total vector $\mathbf{p}$ we have

$$
\|\Delta \mathbf{p}\| \leq\left\|\tilde{K}^{+}\right\|\|\Delta \mathbf{f}-\Delta \mathbf{K} \mathbf{p}\| .
$$

In those cases, when $\mathrm{Df}^{1} 0, \mathrm{DK}=0$ and $\mathrm{Df}=0$, $\mathrm{DK}^{1} 0$ the following estimates are valid respectively

$$
\begin{gathered}
\left|\mathrm{D} p_{j}\right|=\left|\tilde{\mathbf{k}}_{j}^{(+)} \mathrm{D} \mathbf{f}\right|<\left\|\tilde{\mathbf{k}}_{j}^{(+)}\right\|\|\mathrm{Df}\|, \\
\left|\mathrm{D} p_{j}\right|=\left|\tilde{\mathbf{k}}_{j}^{(+)} \mathrm{D} K \mathbf{p}\right|<\left\|\tilde{\mathbf{k}}_{j}^{(+)}\right\|\|\mathrm{D} K \mathbf{p}\| .
\end{gathered}
$$


Let us analyze a system of linear equations (4). It is obvious that here $\mathrm{Df}^{1} 0, \mathrm{DK}=0$ and inequality (6) is valid. Now we find the quantity $\|\mathbf{D f}\|$ :

$$
\mathrm{D} f_{i}=v_{i}^{2}\left(t_{i}-t_{0}\right) d t_{i}=R_{i} v_{i} d t_{i}
$$

The estimate for $\left|\mathrm{D} p_{j}\right|$ will be

$$
\begin{gathered}
\left|\Delta p_{j}\right|=\left|\mathbf{k}_{j}^{(+)} \Delta \mathbf{f}\right|=\sum_{i=1}^{n}\left|k_{j i}^{(+)} \Delta f_{i}\right|= \\
=\sum_{i=1}^{n}\left|k_{j i}^{(+)} R_{i} v_{i} \delta \tau_{\mathrm{i}}\right| \leq \sum_{i=1}^{n}\left|k_{j i}^{(+)} R_{i} v_{i} \rho_{i}\right||\Delta \tau| .
\end{gathered}
$$

Here the weight factors $r_{i}$ reflect both accuracy the arrival times $t_{i}$ of seismic waves on different seismic stations and systematic deviations in determining $t_{i}$ due to the heterogeneity of real structure.

The depth error for our cases is easily found from geometrical considerations [Bur$\min , 1986]$.

$$
\begin{gathered}
|\mathrm{DH}|=H_{1}-H_{2}= \\
=\left[\left(R_{i}+\left|\mathrm{D} R_{i}\right|\right)^{2}-\left(D_{i}-\left|\mathrm{D} D_{i}\right|\right)^{2}\right]^{1 / 2}- \\
-\left[\left(R_{i}-\left|\mathrm{D} R_{i}\right|\right)^{2}-\left(D_{i}+|\mathrm{D} D|_{i}\right)^{2}\right]^{1 / 2},
\end{gathered}
$$

where $\left|\mathrm{D} R_{i}\right|=0.5 \frac{\left|\Delta R_{0}^{2}\right|}{R_{i}}$;

$$
\left(D_{i}\left|\mathrm{D} D_{i}\right|\right)^{2}=\left(X_{i}+\left|\mathrm{D} X_{i}\right|\right)^{2}+\left(Y_{i}-\left|\mathrm{D} Y_{i}\right|\right)^{2}
$$

and

$$
\left|\mathrm{D} D_{i}\right|=\left[\left(X_{i}+\left|\mathrm{D} X_{i}\right|\right)^{2}+\left(Y_{i}-\left|\mathrm{D} Y_{i}\right|\right)^{2}\right]^{1 / 2}-D_{i}^{3} 0
$$

Moreover, if $\left(R_{i}-\left|\mathrm{D} R_{i}\right|\right)^{2} £\left(D_{i}+\left|\mathrm{D} D_{i}\right|\right)^{2}$, then $H_{2}=0$. If $D_{i} £\left|\mathrm{D} D_{i}\right|$ then $H_{1}=R_{i}+\left|\mathrm{D} R_{i}\right|$. If $R_{i} £\left|\mathrm{D} R_{i}\right|$ then $H_{2}=0$. Here $D_{i}$ and $R_{i}$ are the corresponding epicentral and hypocentral distances. If the depth $H$ of the hypocenter is determined from the station closest to the epicenter, then in this case the errors $|\mathrm{DH}|$ in determining the depth, as is easy to see, will be minimal.

Results. Let us now illustrate the ambiguity in determining the depth of hypocenters of earthquakes with real data. Let us consider several earthquakes that, according to the seismological catalog, are located in the earth's crust, but according to the data of [Burmin, Shumlianska, 2015, 2018a; Burmin et al., 2019] are defined as mantle's earthquakes. For the earthquakes that occurred on 17.03.2011 the experimental travel-time curves are presented in Fig. 5, a. Table 1 shows distances and azimuths for the event.

For the Crimean and Caucasian regions, the coordinates of earthquakes, which are given in the corresponding seismological catalogs, were determined using computer programs created on the basis of the methods described in [Kulchitsky et al., 1986; Pustovitenko et al., 2014]. For the Caucasus, the coordinates of the earthquake hypocenters were determined using the HYPO71 program.

Fig. 5 shows the theoretical and experimental travel time curves by a reduction of velocity $10 \mathrm{~km} / \mathrm{s}$ for an earthquake whose coordinates were determined by a standard method by minimizing the functional (1) (Fig. 5, a) and by minimizing the functional (Fig. 5,b).

The points of the experimental travel-time in Fig. 5, $a$ were constructed as follows. The time of occurrence of earthquakes (time in the focus) and coordinates of the epicenters were taken from the catalogs. The arrivals of longitudinal waves at the stations were taken from the bulletins. The travel-times of longitudinal seismic waves were defined as the difference between the arrival times of waves at the stations and the source's time. Epicentral distances were determined by solving the inverse geodesic problem on the coordinates of seismic stations and epicenters of earthquakes.

According to the catalog, the time of occurrence of earthquake is 02:13:27.7. Coordinates of the epicenter are $43.39 \mathrm{~N} 36.13 \mathrm{E}$. The depth of the hypocenter is $31 \mathrm{~km}$. After recounting, the time in the focus is 02:13:26.16, the coordinates of the epicenter are $43.49 \mathrm{~N}$ $36.26 \mathrm{E}$ and the depth of the hypocenter is $122 \mathrm{~km}$. The difference between the time of occurrence of an earthquake according to the 
Ta b le 1. Distances and azimuths for the event 17.03.2011, $M w=4.3$

\begin{tabular}{|c|c|c|c|c|c|}
\hline $\begin{array}{c}\text { Code of sta- } \\
\text { tion }\end{array}$ & Latitude & Longitude & $\begin{array}{c}\text { Distances, } \\
\mathrm{km}\end{array}$ & Direct Az & Inverse Az \\
\hline VSR & 51,21 & 39,16 & 884.6 & 13.27 & 195.40 \\
ODE & 46.48 & 30.71 & 548.34 & 305.86 & 5.33 \\
KIV & 43.95 & 42.68 & 525.92 & 78.83 & 1.37 \\
SOC & 43.58 & 39.71 & 291.52 & 83.05 & 1.44 \\
KGU & 45.02 & 39.03 & 278.61 & 51.50 & 233.43 \\
BZK & 41.96 & 34 & 263.35 & 224.83 & 3.92 \\
SIM & 44.95 & 34.12 & 246.17 & 310.86 & 5.42 \\
SEV & 44.54 & 33.68 & 223.66 & 296.93 & 5.18 \\
YAL & 44.48 & 34.15 & 204.21 & 300.35 & 5.24 \\
FEO & 45.02 & 35.39 & 183.15 & 338.07 & 157.47 \\
ALU & 44.68 & 34.4 & 180.71 & 308.85 & 5.39 \\
ANN & 44.8 & 37.43 & 173.74 & 29.06 & 0.50 \\
KER & 45.31 & 36.46 & 168.72 & 353.03 & 172.85 \\
SDK & 44.89 & 35 & 167.69 & 324.13 & 5.65 \\
\hline
\end{tabular}
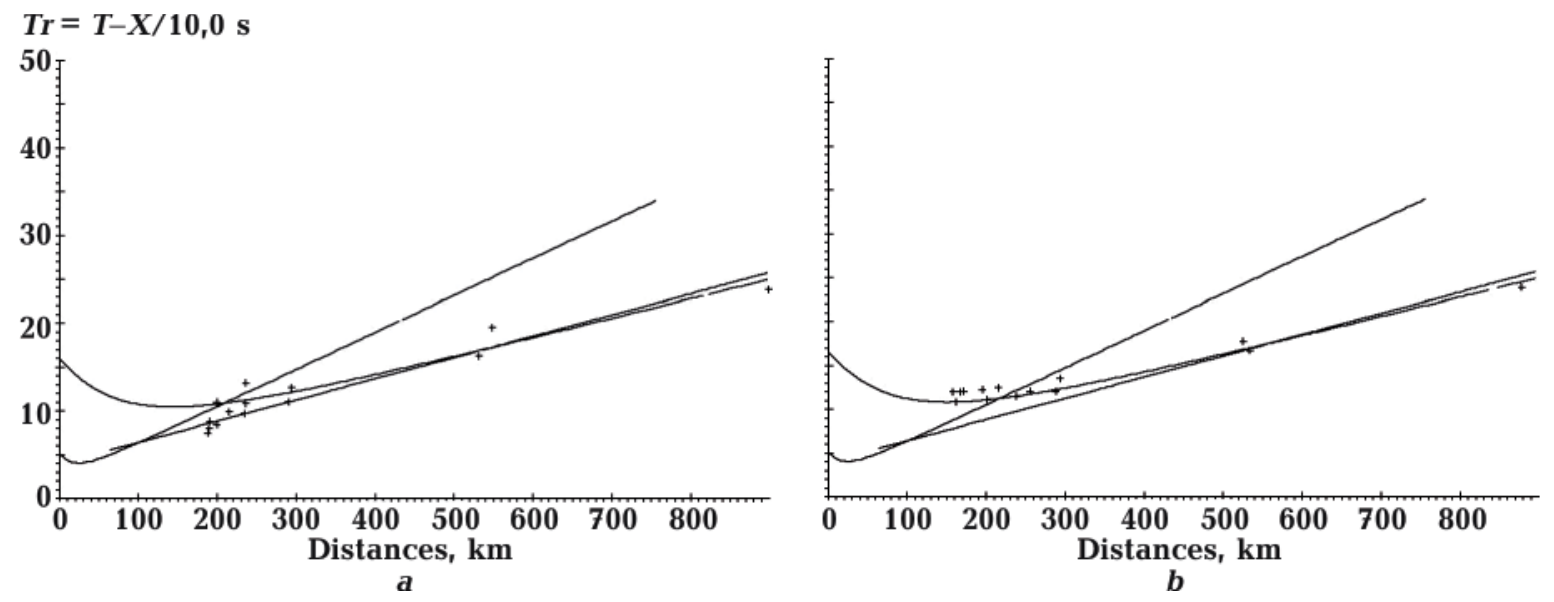

Fig. 5. Experimental points of the hodograph of the earthquake that took place on 17.03.2011 according to the catalog $(a)$ and after recalculation $(b)$ and theoretical travel curves for the depths of the sources of $31 \mathrm{~km}$ and $122 \mathrm{~km}$.

bulletin and the one we determined is 1.54 seconds. The earthquake was recorded at 14 stations of the Crimean seismological service and stations of the Geophysical Service of Russia.

In Fig. 5, $a$, one can see a significant deviation of the points relative to the theoretical travel-time curves, which indicates ambiguity in determining the depth of the hypocenter of the earthquake. In Fig. 5, $b$, the experimental points correspond to a minimum of the functional (2). It can be seen that all points gravitate towards a theoretical hodograph for a source with a depth of $122 \mathrm{~km}$.
Fig. 6 shows the travel time curves for the earthquake on 31.07.2006. The bulletin for this earthquake presents three options with different times in the focus and, correspondingly, coordinates and depth: 1) the time of occurrence of earthquake is 09:04:32.8, the coordinates are $46.87 \mathrm{~N} 36.67 \mathrm{E}$ and the depth is $20 \mathrm{~km}$; 2) the time of occurrence of earthquake is 09:04:33.3, the coordinates are $46.74 \mathrm{~N} 37.06 \mathrm{E}$ and the depth is $53 \mathrm{~km} ; 3$ ) the time of occurrence of earthquake is 09:04:28.8, the coordinates are $46.95 \mathrm{~N} 37.00 \mathrm{E}$ and the depth is $24 \mathrm{~km}$. Table 2 shows distances and azimuths for the event. 
Ta ble 2. Distances and azimuths for the event 31.07.2006, $M w=4.2$

\begin{tabular}{|c|c|c|c|c|c|}
\hline $\begin{array}{c}\text { Code of sta- } \\
\text { tion }\end{array}$ & Latitude & Longitude & $\begin{array}{c}\text { Distances, } \\
\mathrm{km}\end{array}$ & Direct Az & Inverse Az \\
\hline KORU & 48.15 & 23.13 & 998.00 & 299.90 & 109.90 \\
RAK & 48.03 & 24.17 & 954.07 & 300.63 & 111.38 \\
HORU & 49.21 & 26.42 & 884.09 & 311.01 & 123.30 \\
KMPU & 48.56 & 26.46 & 840.61 & 288.38 & 5.03 \\
NDNU & 48.59 & 27.36 & 790.36 & 289.9 & 5.05 \\
PUGU & 47.49 & 34.10 & 736.16 & 303.02 & 116.10 \\
YAL & 44.48 & 34.15 & 327.16 & 229.31 & 4.00 \\
SIM & 44.95 & 34.12 & 307.36 & 238.32 & 4.15 \\
SEV & 44.54 & 33.68 & 286.58 & 234.41 & 4.09 \\
ALU & 44.68 & 34.4 & 273.66 & 230.37 & 4.02 \\
FEO & 45.02 & 35.39 & 196.59 & 224.96 & 3.92 \\
SDK & 44.89 & 35 & 183.66 & 227.64 & 3.97 \\
ANN & 44.8 & 37.43 & 147.58 & 167.19 & 2.91 \\
\hline
\end{tabular}
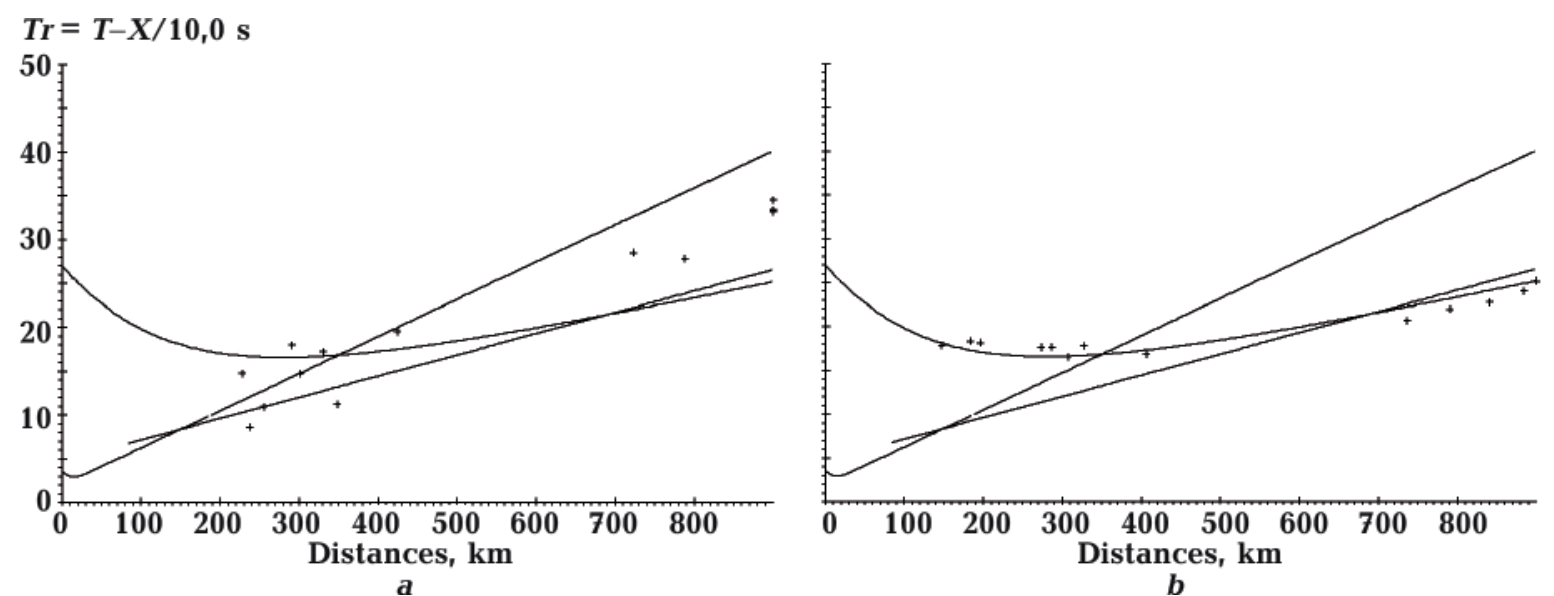

Fig. 6. Experimental points of the hodograph of the earthquake that occurred on 31.07.2006 according to the catalog $(a)$ and after the recalculation $(b)$ and theoretical travel time curves for the depths of the sources of $20 \mathrm{~km}$ and $206 \mathrm{~km}$.

The time of occurrence of the earthquake after recalculation is 09:04:32.57 with the coordinates $46.11 \mathrm{~N} 37.14 \mathrm{E}$ at the hypocenter depth of $206 \mathrm{~km}$. The earthquake was recorded at 21 stations of the Crimean, Ukrainian, Russian and Romanian seismological networks. The first $P$-wave arrivals can be identified at 11 stations.

Points for nearby stations, built according to the Bulletin (Fig. 6, a) are located with a large deviation and do not coincide either with the theoretical hodograph for a source depth of $20 \mathrm{~km}$, nor with a travel time curve for $206 \mathrm{~km}$. After the recalculation, the points are ordered along the theoretical hodograph for a depth of $206 \mathrm{~km}$ (Fig. 6, b).

Fig. 7 shows the travel-time curves for the earthquake on 30.01.2004. Time in the focus by the bulletin is 05:09:26, coordinates are $42.66 \mathrm{~N} 36.70 \mathrm{E}$ and the depth of the focal point is $22 \mathrm{~km}$. Time in the focus after recounting is 05:09:24.91, with coordinates $43.61 \mathrm{~N}$ $37.07 \mathrm{E}$ and depth of the focus $226 \mathrm{~km}$. Table 3 Distances and azimuths for the event.

This event was registered by six stations of the Crimean seismological network and by one station of the Russian seismological service. The scatter of the points constructed 
Ta b le 3. Distances and azimuths for the event 30.01.2004, $M w=4.5$

\begin{tabular}{|c|c|c|c|c|c|}
\hline $\begin{array}{c}\text { Code of sta- } \\
\text { tion }\end{array}$ & Latitude & Longitude & $\begin{array}{c}\text { Distances, } \\
\mathrm{km}\end{array}$ & Direct Az & Inverse Az \\
\hline SIM & 44.95 & 34.12 & 312.23 & 297.89 & 5.19 \\
SEV & 44.54 & 33.68 & 282.54 & 286.72 & 5.00 \\
ALU & 44.68 & 34.4 & 254.78 & 294.39 & 5.13 \\
YAL & 44.48 & 34.15 & 240.45 & 287.95 & 5.02 \\
SDK & 44.89 & 35 & 219.89 & 305.52 & 5.33 \\
SOC & 43.6 & 39.7 & 218.21 & 87.06 & 1.51 \\
ANN & 44.8 & 37.43 & 107.35 & 6.47 & 0.11 \\
\hline
\end{tabular}

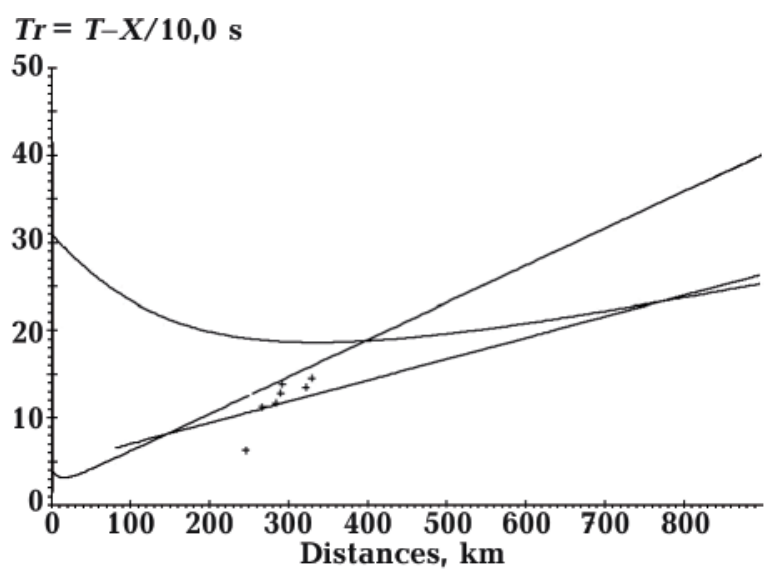

a

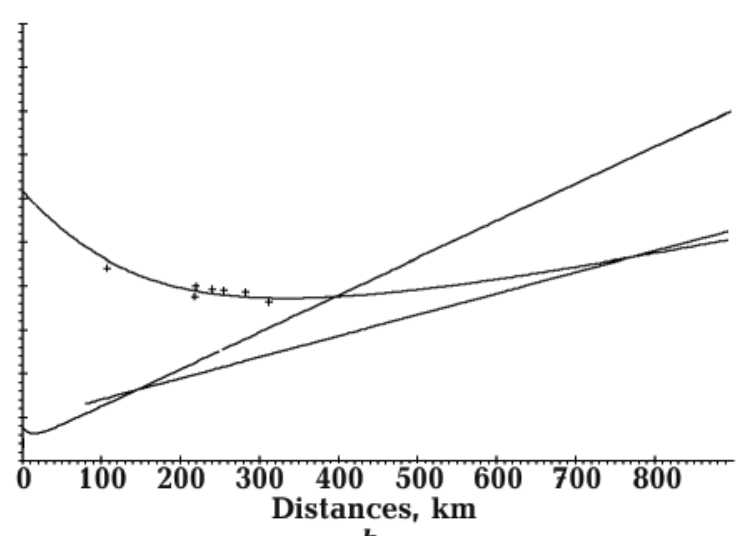

b

Fig. 7. Experimental points of the hodograph of the earthquake that occurred on 30.01.2004 according to the catalog $(a)$ and after the recalculation $(b)$ and the theoretical travel time curves for the depths of the sources are $22 \mathrm{~km}$ and $226 \mathrm{~km}$.

Ta b le 4. Distances and azimuths for the event 04.03.2001, $M w=4.7$

\begin{tabular}{|c|c|c|c|c|c|}
\hline $\begin{array}{c}\text { Code } \\
\text { of station }\end{array}$ & Latitude & Longitude & $\begin{array}{c}\text { Distances, } \\
\mathrm{km}\end{array}$ & Direct Az & Inverse Az \\
\hline SOC & 43.6 & 39.7 & 352.26 & 75.14 & 1.31 \\
DNZ & 45.55 & 33.1 & 313.01 & 326.16 & 5.69 \\
KER & 45.31 & 36.46 & 286.39 & 16.51 & 0.28 \\
SIM & 44.95 & 34.12 & 249.39 & 333.89 & 5.82 \\
FEO & 45.02 & 35.39 & 218.06 & 358.8 & 6.26 \\
SEV & 44.54 & 33.68 & 216.33 & 320.37 & 5.59 \\
SDK & 44.89 & 35 & 205.62 & 350.56 & 6.11 \\
ALU & 44.68 & 34.4 & 200.31 & 336.15 & 5.86 \\
YAL & 44.48 & 34.15 & 190.41 & 328.06 & 5.72 \\
\hline
\end{tabular}

from the data on the source according to the bulletin concerning the theoretical travel time curves for depths of 22 and $226 \mathrm{~km}$ is shown in Fig. 7, a. All points except one for the ANN station are located between the upper and lower branches of the theoretical travel time curve for a depth of $22 \mathrm{~km}$. The point for the ANN station lies well below the travel curve. The points obtained after the recalculation (Fig. 7, b) are in accordance with the theoretical travel time curves for a depth of $226 \mathrm{~km}$. 

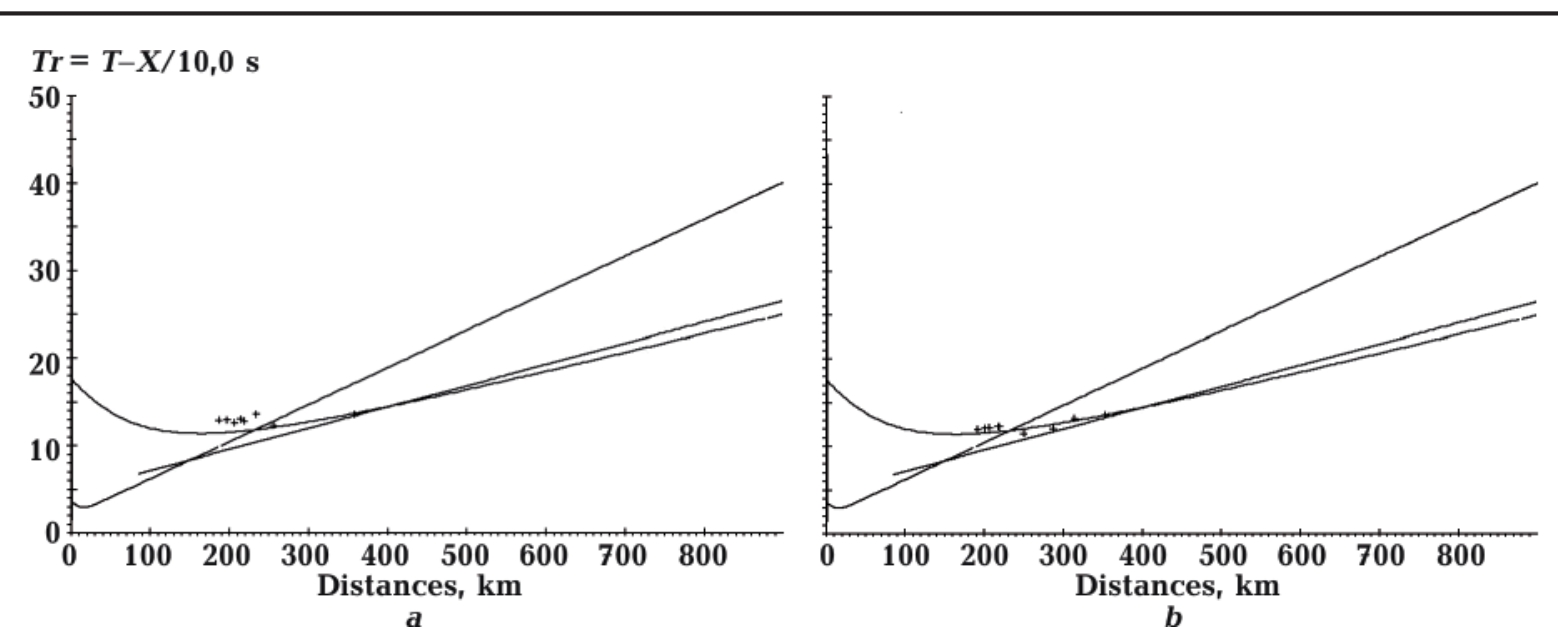

Fig. 8. Experimental points of the hodograph of the earthquake that took place on 04.03.2001 according to the catalog $(a)$ and after recalculation $(b)$ and theoretical travel time curves for the depths of the sources of $20 \mathrm{~km}$ and $130 \mathrm{~km}$.

Fig. 8 shows travel-time for the earthquake on 04.03.2001. The time in the focus according to the bulletin is $23: 31: 1.2$, the coordinates of the bulletin are $43.06 \mathrm{~N} 35.37 \mathrm{E}$ and the depth of the focus is $20 \mathrm{~km}$. The time in the focus after recalculation is 23:31:1.67, the coordinates are $42.99 \mathrm{~N} 35.31 \mathrm{E}$ and the depth is $130 \mathrm{~km}$. Table 4 shows distances and azimuths for the event.

The event was recorded at nine stations by the Crimean network of the seismological service and the Russian Service. The first arrival of $P$-waves is defined as accurate at 6 stations. At KER and DNZ stations, the phase of the first entry is not defined. Points obtained from the data on the focus on the Bulletin, in Fig. 8A lie even above than the theoretical hodograph from the source of $130 \mathrm{~km}$, although according to the catalog they should fall on the hodograph from the depth of the source of $20 \mathrm{~km}$. Points obtained from the data on the foci after recalculation (Fig. 8, b) are located along the line of the theoretical hodograph for a depth of $130 \mathrm{~km}$.

Seismological stations recording the earthquakes of the Caucasus are located on the territory of several states: Russia, Armenia, Georgia, Azerbaijan, Iran and Turkey. The velocity model is taken from the article devoted to the recalculation of the hypocenters of the Caucasus [Burmin et al., 2019].

Fig. 9 shows the points of the hodograph for the earthquake occurred on 18.07.1997.
The time in the focus according to the bulletin is 07:33:53.5, the coordinates for the bulletin are $41.10 \mathrm{~N} 45.11 \mathrm{E}$ and the depth is five $\mathrm{km}$. After recounting, the time in the focus is 07:33:51.99. The time difference in the focus is $1.51 \mathrm{~s}$. The coordinates of the epicenter are $41.90 \mathrm{~N} 45.88 \mathrm{E}$ and the depth of the focus after recounting is $331 \mathrm{~km}$.

The event was recorded at the stations of the seismological services of Russia, Armenia and Iran. The scatter of points from the data in the focus from the bulletin is large (Fig. 9, a).

The theoretical hodograph, for the hypocenter depth of seven $\mathrm{km}$ indicated in the Bulletin, is located above these points. Recalculation with new data on the focus shows a good coincidence of the obtained points (Fig. 9, $b$ ) with a theoretical hodograph for a depth of $331 \mathrm{~km}$. Table 5 shows distances and azimuths for the event 18.07.1997.

For the earthquake 12.06.2006, the time in the focus according to the bulletin is 16:21:56.2, the coordinates are $40.61 \mathrm{~N} 49.24 \mathrm{E}$ and the depth is $0 \mathrm{~km}$. After recalculation, the time in the focus is 16:21:53.62; the coordinates are 41.41 N. $49.51 \mathrm{E}$ and the depth of $160 \mathrm{~km}$. The event was recorded at the stations of Russia, Armenia, Turkey, and Iran. All points calculated from the data on the focus taken from the bulletin are much lower than the theoretical hodograph for a depth of $0 \mathrm{~km}$ (Fig. 10,a). The points obtained from the recalculated data on the source fit well on the 
Ta b l e 5. Distances and azimuths for the event 18.07.1997, $M w=4.4$

\begin{tabular}{|c|c|c|c|c|c|}
\hline $\begin{array}{c}\text { Code } \\
\text { of station }\end{array}$ & Latitude & Longitude & $\begin{array}{c}\text { Distances, } \\
\mathrm{km}\end{array}$ & Direct Az & Inverse Az \\
\hline SOC & 43.6 & 39.7 & 654.72 & 289.57 & 5.05 \\
TAB & 38.06 & 46.32 & 426.07 & 176.24 & 3.07 \\
KIV & 43.95 & 42.68 & 315.88 & 307.59 & 5.36 \\
PYA & 44.03 & 43.06 & 288.26 & 311.93 & 5.44 \\
KBZ & 43.73 & 43.89 & 273.02 & 305.93 & 5.33 \\
MAK & 42.96 & 47.5 & 255.34 & 45.96 & 0.80 \\
\hline
\end{tabular}
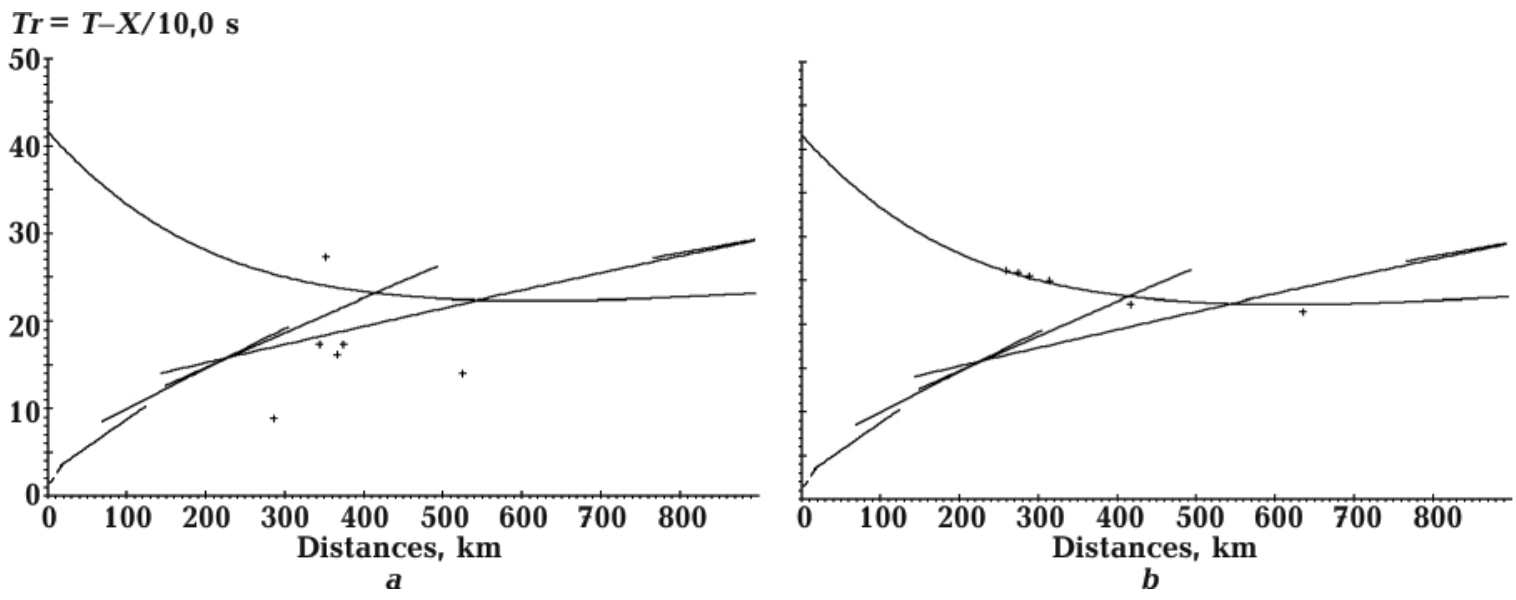

Fig. 9. Experimental points of the hodograph of the earthquake that occurred on 18.07.1997 according to the catalog (a) and after the recalculation (b) and the theoretical travel time curves for the source depths of $5 \mathrm{~km}$ and $331 \mathrm{~km}$.

Ta b le 6. Distances and azimuths for the event 12.06.2006, $M w=4.2$

\begin{tabular}{|c|c|c|c|c|c|}
\hline $\begin{array}{c}\text { Code } \\
\text { of station }\end{array}$ & Latitude & Longitude & Distances. km & Direct Az & Inverse Az \\
\hline MTA & 41.69 & 44.79 & 398.62 & 272.64 & 4.75 \\
GNI & 40.15 & 44.74 & 398.98 & 248.95 & 4.34 \\
DLMC & 40.56 & 29 & 360.1 & 327.64 & 5.71 \\
BUJR & 42.82 & 47.11 & 345.53 & 305.44 & 5.33 \\
DGRG & 41.45 & 45.37 & 349.89 & 268.61 & 4.68 \\
BTLK & 38.41 & 42.1 & 333.68 & 294.74 & 5.14 \\
MAK & 42.96 & 47.5 & 334.72 & 313.14 & 5.46 \\
DBC & 43.02 & 46.83 & 326.68 & 305.66 & 5.33 \\
XNZR & 42.54 & 46.7 & 320.96 & 300.1 & 5.23 \\
UNCK & 40.11 & 28.72 & 312.68 & 300.13 & 5.23 \\
GNBR & 42.38 & 46.96 & 247.25 & 294.5 & 5.14 \\
SGKR & 42.45 & 47.65 & 230.82 & 304.13 & 5.30 \\
URKR & 42.16 & 47.63 & 191.64 & 295.07 & 5.14 \\
DRN & 42.03 & 48.33 & 136.42 & 300.85 & 5.25 \\
AKT & 41.48 & 47.73 & 106.98 & 269.95 & 4.71 \\
KSMR & 41.6 & 48.13 & 57.36 & 277.11 & 4.83 \\
\hline
\end{tabular}



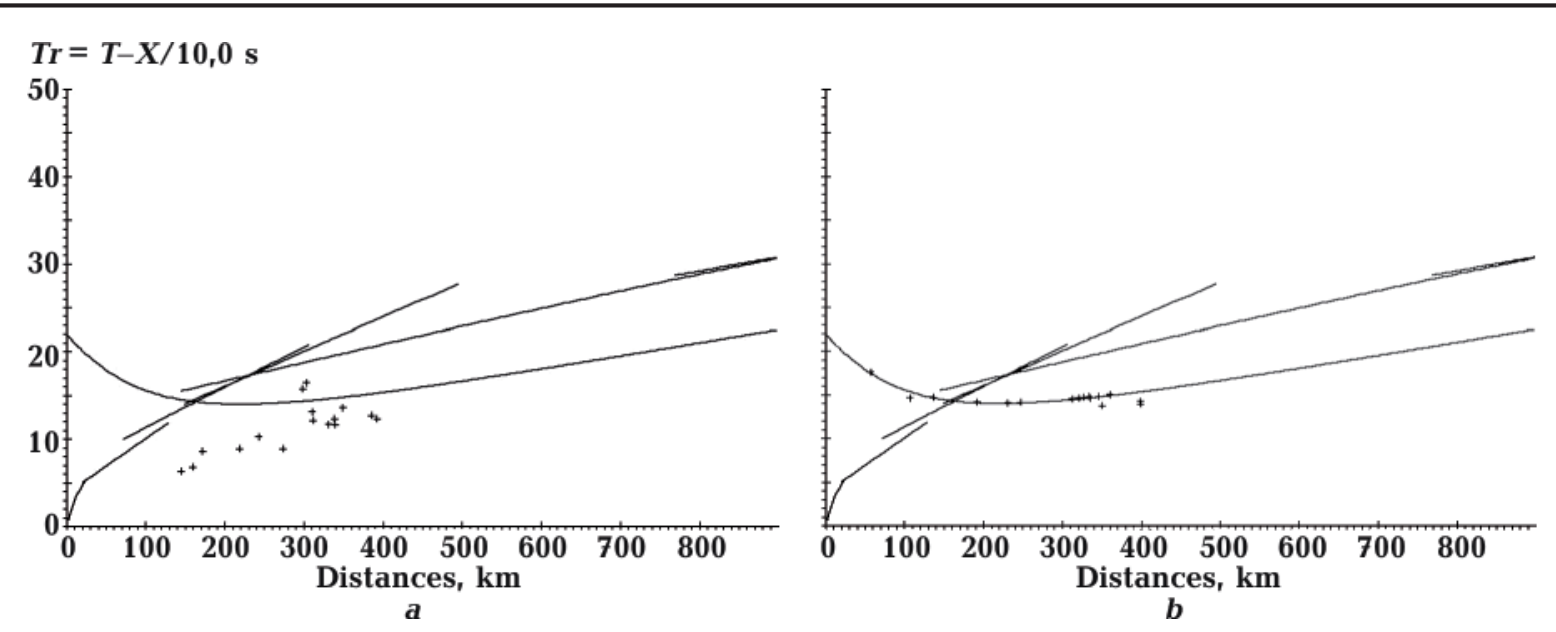

Fig. 10. Experimental points of the hodograph of the earthquake occurred on 12.06.2006 according to the catalog $(a)$ and after the recalculation $(b)$ and the theoretical travel time curves for the depths of the sources $0 \mathrm{~km}$ and $160 \mathrm{~km}$.

Ta b l e 7. Distances and azimuths for the event 25.08.2009, $M w=3.6$

\begin{tabular}{|c|c|c|c|c|c|}
\hline $\begin{array}{c}\text { Code } \\
\text { of station }\end{array}$ & Latitude & Longitude & $\begin{array}{c}\text { Distances, } \\
\mathrm{km}\end{array}$ & Direct Az & Inverse Az \\
\hline PQL & 40.79 & 48.59 & 409.29 & 93.67 & 1.63 \\
IML & 40.79 & 48.18 & 340.06 & 94.25 & 1.64 \\
BTK & 43.37 & 44.54 & 271.75 & 4.84 & 0.08 \\
STDR & 43.37 & 44.06 & 266.11 & 356.11 & 6.21 \\
SNJR & 43.06 & 44.81 & 261.51 & 11.15 & 0.19 \\
SEK & 41.21 & 47.19 & 250.65 & 83.5 & 1.45 \\
NAK & 39.2 & 45.41 & 257.1 & 154.83 & 2.70 \\
BRD & 42.26 & 47.17 & 245.93 & 60.52 & 1.05 \\
ARD & 43.18 & 44.28 & 234.82 & 0.2 & 0.00 \\
KOR & 43.08 & 44.06 & 231.14 & 355.75 & 6.20 \\
DIG & 42.9 & 43.58 & 192.07 & 344.36 & 6.01 \\
GAN & 40.64 & 46.32 & 133.63 & 104.93 & 1.83 \\
\hline
\end{tabular}
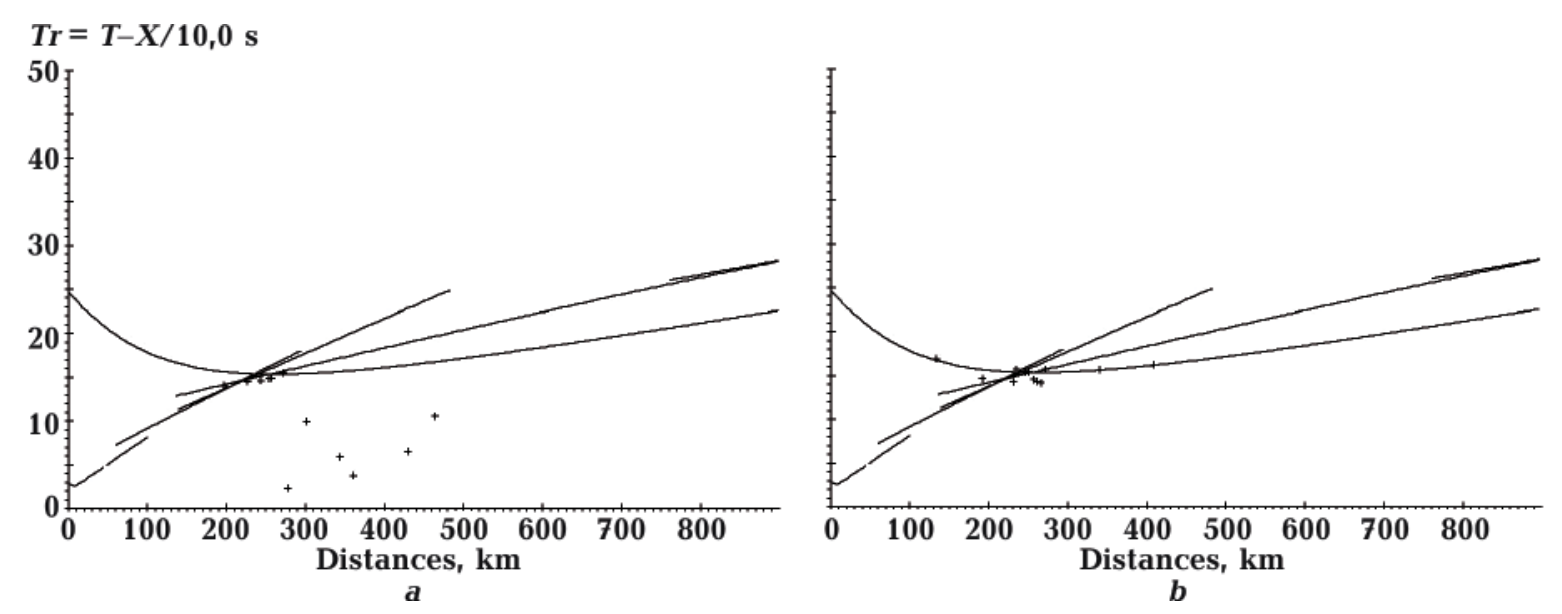

Fig. 11. Experimental points of the hodograph of the earthquake that occurred on 25.08.2009 according to the catalog $(a)$ and after the recalculation $(b)$ and theoretical travel curves for the depths of the sources of $12 \mathrm{~km}$ and $183 \mathrm{~km}$. 
theoretical hodograph for a depth of $160 \mathrm{~km}$ (Fig. 10, b). Table 6 shows distances and azimuths for the event on 12.06.2006.

For the earthquake 25.08.2009 (Fig. 11), the time in the focus was according to the bul-

Ta b le 8. The velocity model for calculating the theoretical travel time curves

\begin{tabular}{|c|c|c|}
\hline $\begin{array}{c}\text { Depth of } \\
\text { boundary, } \\
\mathrm{km}\end{array}$ & $\begin{array}{c}\text { The velocity of the } \\
P \text {-wave above the } \\
\text { boundary, km/s }\end{array}$ & $\begin{array}{c}\text { The velocity of the } \\
P \text {-wave under the } \\
\text { boundary, km/s }\end{array}$ \\
\hline .00 & 0.00 & 3.00 \\
3.00 & 5.40 & 5.40 \\
18.00 & 6.30 & 7.00 \\
46.00 & 7.00 & 8.00 \\
116.82 & 7.93 & 8.45 \\
132.42 & 8.46 & 8.46 \\
132.45 & 8.20 & 8.20 \\
294.54 & 8.50 & 8.50 \\
294.60 & 8.87 & 8.87 \\
301.77 & 8.89 & 8.89 \\
344.90 & 9.03 & 9.03 \\
412.59 & 9.10 & 9.30 \\
476.11 & 9.64 & 9.64 \\
508.01 & 9.79 & 9.79 \\
519.66 & 9.83 & 9.83 \\
555.04 & 9.95 & 9.95 \\
640.00 & 9.95 & 9.95 \\
\hline
\end{tabular}

letin is 23:43:33.7, the coordinates are $41.17 \mathrm{~N}$ $43.10 \mathrm{E}$, the depth is $12 \mathrm{~km}$. After the recalculation, the time in the focus is 23:43:33.50, the coordinates are 41.07 N. $44.27 \mathrm{E}$ and the depth is $183 \mathrm{~km}$. The event was recorded at the stations of Russia, Turkey and Armenia. Half of the points, according to the bulletin, are located along the lower branch of the theoretical hodograph for a depth of $12 \mathrm{~km}$ (Fig. 11,a), the rest are randomly scattered much lower. The points obtained from the calculated data on the foci practically all rely on the theoretical hodograph for a depth of $183 \mathrm{~km}$ (Fig. 11, b). Table 7 show distances and azimuths for the event 25.08.2009.

Figures 12 and 13 shows the distribution of maximum errors in the determination of the depths of earthquake hypocenters in the Black Sea and in the Caucasus, recorded mainly by the Crimean and Caucasian seismic stations. The errors were calculated by formulas (7). When calculating the errors, it was assumed that the earthquake foci were located at a depth of $200 \mathrm{~km}$, errors in determining the time of passage of seismic waves from the foci to seismic stations were $0.1 \mathrm{~s}$, errors in the velocity of seismic waves $0.1 \mathrm{~km} / \mathrm{s}$.

Fig. 12, 13 show maximum errors of determining the depth. Errors are about two km

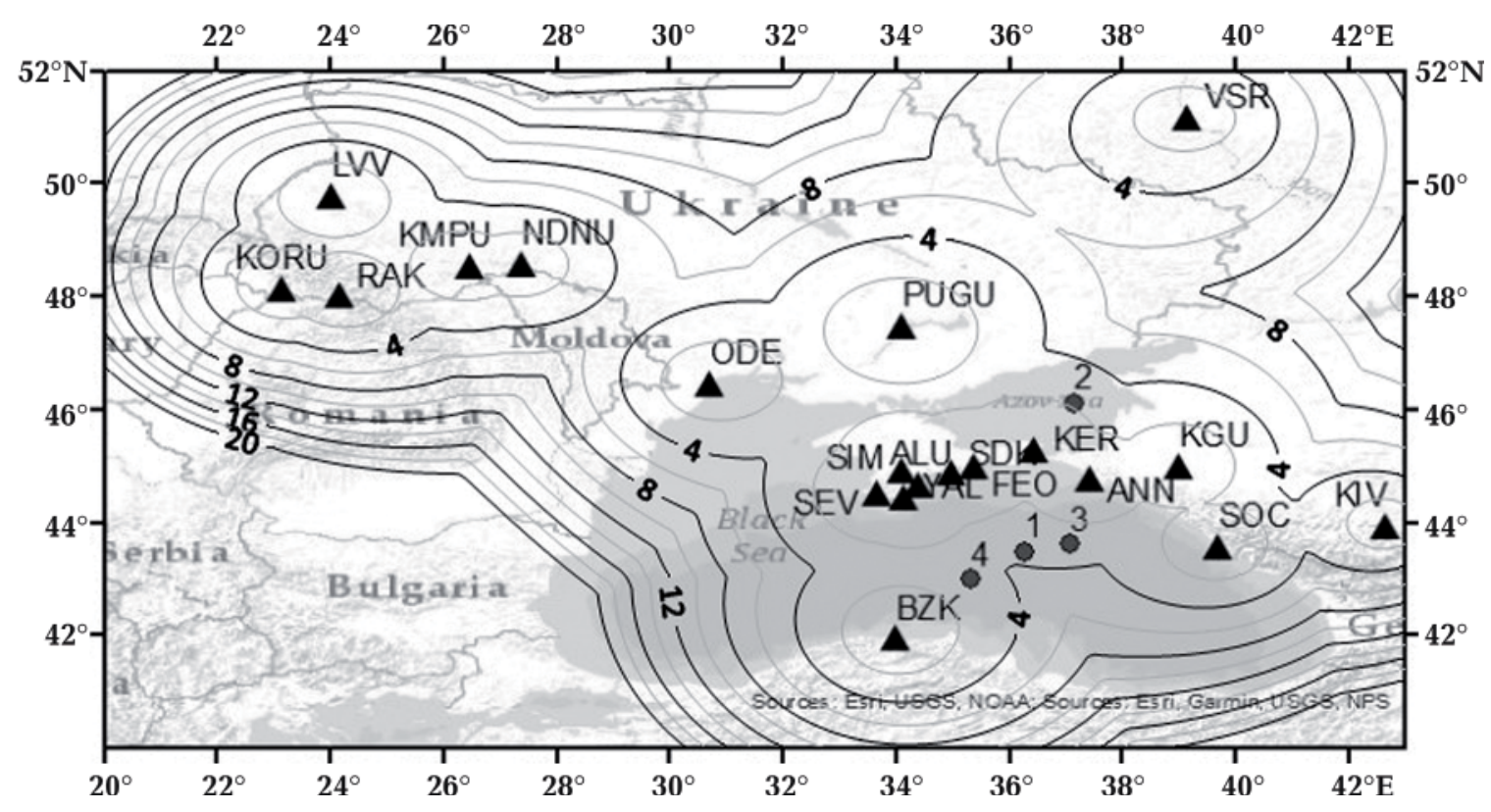

Fig. 12. The distribution of errors in determining the depth of hypocenters for the Crimean-Black Sea region for the Crimean and its nearest stations. 


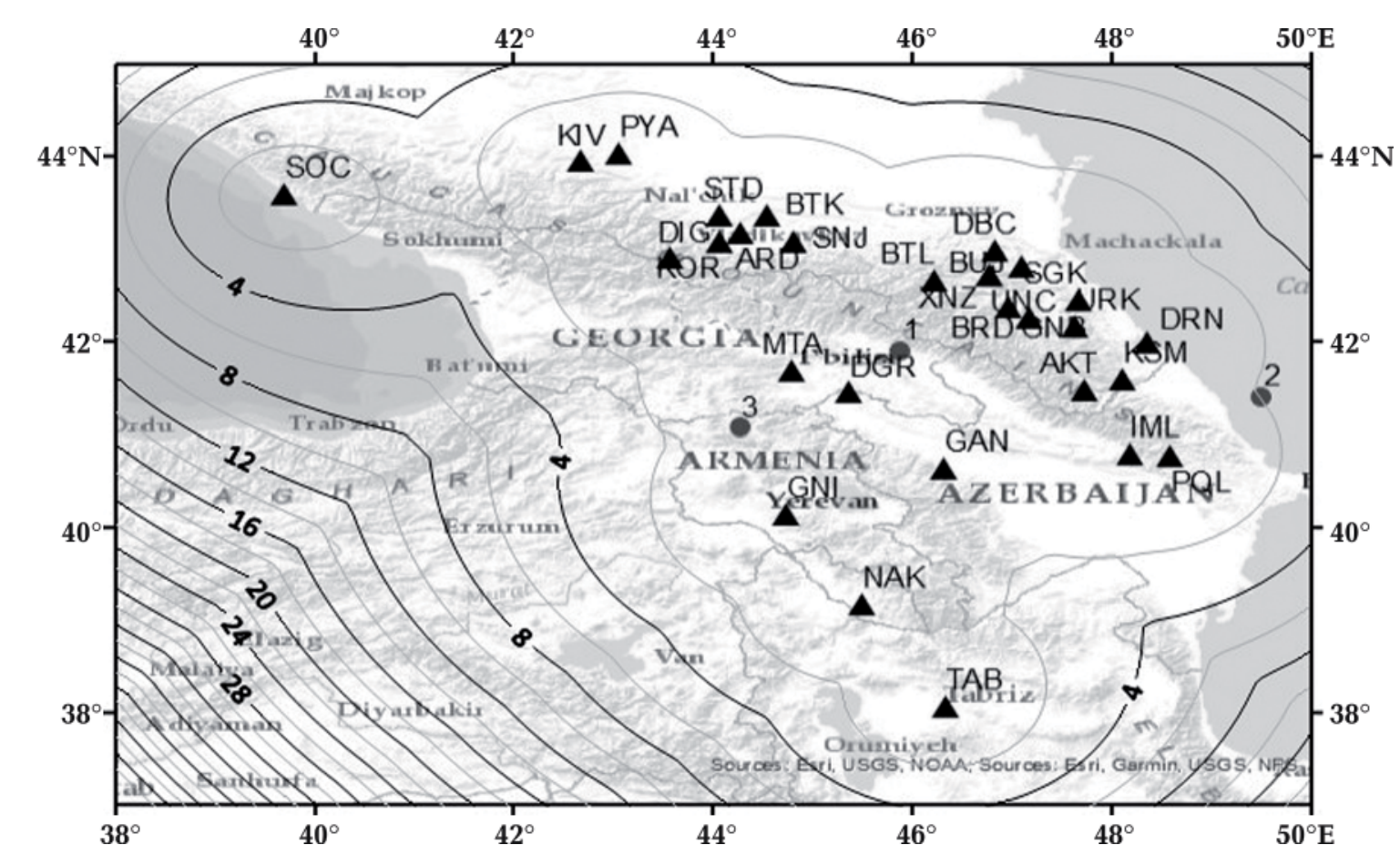

Fig. 13. The distribution of errors in determining the depth of the Caucasus Hypocenters.

within networks and four $\mathrm{km}$ at the periphery of networks.

Discussion. In earlier works, the authors have already pointed to the reason why deep earthquakes in the Crimea, the Black Sea and the Caucasus could not be detected [Burmin, Shumlianska, 2017b]. The reason is that, prior to the $1980 \mathrm{~s}$, to determine the coordinates of the hypocenters of the Crimean and Caucasian earthquakes, hodographs, constructed by A. Ya. Levitskaya back in 1947 (1948) only for depths of 5, 15, 25 and $35 \mathrm{~km}$, were used. In the early $1980 \mathrm{~s}$, new travel time curves were constructed for the depths of $0,5,10,15,20$, 25, 30 and $35 \mathrm{~km}$ [Kulchitsky et al., 1986; Pustovitenko et al., 2014].

According to [Godzikowska, 1988], to determine the coordinates of the hypocenters of the earthquakes a discrete set of hodographs limited to depths of $120-150 \mathrm{~km}$ was used. It is obvious that by using travel time curves for shallow sources, deep earthquakes in principle cannot be determined.

The origin of mantle earthquakes in the Caucasian and Crimean-Black Sea regions cannot be explained without understanding the deformation environment. Reconstruc- tions of the type of seismotectonic deformation of the Earth's crust in the Caucasus and its immediate surroundings, based on a combination of earthquake focal mechanisms, show the setting of thrusting with a subhorizontal orientation of the main compression axis (in the north-north-east direction, across the strike of the Caucasian structures) and a sub-vertical orientation of the main extension axis [Lukk et al., 2019]. On the whole, this is quite consistent with the concepts developed within the framework of the plate tectonic concept about the transverse narrowing of the Caucasian segment of the Alpine-Himalayan belt as a result of the convergence of the Arabian and Eurasian lithospheric plates.

At the same time, because of detailed geodetic measurements carried out on the territory of the Greater Caucasus, displacements of GPS points are observed, indicating an increase in its width. This increase cannot be associated with stretching across the strike of the Caucasus, since the solutions to the mechanisms of earthquake sources in its territory unambiguously indicate that there are compression stresses across the strike of geological structures. The obtained fact is ex- 
plained by the active increase in the volume (and, in particular, the area) of layered rocks of the Greater Caucasus and the occurrence of rock separation as a result, apparently, of the influx of additional mineral material into them, introduced by ascending flows of deep fluids [Shevchenko et al., 2017].

The existence of a seismogenic mantle «body» within the eastern part of the Caucasian Isthmus between the Black and Caspian Seas [Shevchenko et al., 2020], within which, according to Gabtasarova [2010], most mantle earthquakes occur, are associated with ascending flows of fluid matter. It plunges in the direction from the southeast to the northwest to a depth of $160 \mathrm{~km}$ and significantly expands in the depth interval of 50-75 km in the southeast direction. The type of seismotectonic deformation of this deep mantle body, which is determined by the totality of focal earthquake mechanisms, is due to the prevalence of subhorizontal elongation in the near-meridional direction. It is fundamentally different from that for the upper layer of the earth's crust, where rock material, according to the totality of focal mechanisms of crustal earthquakes, is deformed under conditions of prevalence of subhorizontal compression across the strike of the tectonic structures of the Greater Caucasus.

Similar seismogenic «inclined pillars» of irregular shape are known in the Alboran Sea, where they can be traced to depths of 500-700 km [Blanco et al., 1993], and in the Tyrrhenian Sea up to 300-400 km [Koulakov et al., 2009]. These bodies appear as highspeed anomalies. On longitudinal sections, they look like sinking lithospheric plates, slabs. On cross-sections, they have an irregular shape followed by flattening with depth, which makes it difficult to identify them as subduction zones.

Such «bodies» are assumed to be zones of permeability, zones of migration of fluids or melts [Aptikaeva et al., 1994; Gorbatikov et al., 2015]. However, the representation of these zones in the form of high-velocity anomalies does not provide grounds for such an assumption; fluid flows will most likely lead to a decrease in the velocities of seismic waves when passing through the earth's crust and mantle.

The origin of mantle earthquakes in the Vrancea zone is given in [Trifonov et al., 2012], associating earthquakes with decompaction of the upper mantle. This leads to the separation and subsidence of dense and cold metabasic slabs into the asthenosphere. The energy of earthquakes, in addition to the load on the slab, is also fed by the phase transformations of its rocks: deserpentinization, lower eclogitization of the remains of less metamorphosed basic rocks and the transition of quartz to coesite, and the cause of seismogenic movements can be not so much high deviatoric stresses, but a decrease in the strength of rocks in the zones of mylonitization with increased impact fluids [Rodkin et al., 2009]. Their sources are the dehydration products of serpentine and amphiboles and, possibly, the asthenosphere. Thus, the subsidence of seismogenic slabs and the intense uplift of the mountains occurred simultaneously and were caused by a single reason the decompaction of the upper mantle under the influence of the asthenosphere.

As applied to the Caucasus region, our assumptions are based on the above studies, as well as on the seismotomographic models of the upper mantle by Koulakov et al. [2012] and the local crustal model [Zabelina et al., 2016]. According to these articles, there is practically no mantle lithosphere under the Caucasus, as evidenced by a low-velocity anomaly at depths of $100-300 \mathrm{~km}$ under the Greater and Lesser Caucasus. In this case, the hot asthenosphere was directly under the crust, which leads to the eruptions of young volcanoes. The lithosphere has lost its solid foundation because of the volumetric expansion of the earth's crust. Also, seismic tomography made it possible to identify parts of the mantle lithosphere, which sink in the form of high-speed slabs along the edges of the collision zone of the Arabian and Eurasian plates.

From the studies mentioned above, it follows that seismicity in the Caucasus region at different depth levels is associated with various processes.

In the earth's crust, earthquake foci are 
caused by deformations under conditions of predominance of subhorizontal compression across the strike of the tectonic structures of the Greater Caucasus.

The nature of the mantle seismicity of the Caucasus is associated with the separation and subsidence of the lower part of the lithosphere into the asthenospheric layer. Shevchenko et al. [2020] showed a submerging seismogenic body at depths of $50-160 \mathrm{~km}$. The seismotectonic deformation of this mantle body differs from the deformations noted in the earth's crust and is determined by the prevalence of subhorizontal elongation in the near-meridional direction. However, in our opinion, it is erroneous to associate the origin of earthquake sources following Shevchenko [Shevchenko et al., 2020] with a subvertical column of rising fluids, since according to seismotomographic sections [Koulakov et al., 2012], this formation is most likely associated with a highvelocity layer, and fluids lead to a decrease in viscosity, which leads to a decrease in the velocities of seismic waves. Thus, the high velocity layer is possibly a slab. In the slab, earthquakes are associated not only with its subsidence, but also with phase transformations of rocks [Rodkin et al., 2009], and possible fluids in this process are consequences of phase transformations and do not play a major role in the formation of earthquake foci.

According to Koulakov [2012], at a depth of $100-300 \mathrm{~km}$, there is a low-velocity layer associated with the asthenosphere. The earthquakes occurring in it cannot have tectonic, shear causes. The asthenosphere is a source of fluids and high-temperature fluids, including melts, then earthquakes that originate in this layer will be associated with the release of fluids during phase transformations and their passage through the mantle. In zones of phase transformations at such depths, jump-like instability cannot arise. Therefore, the mechanisms of mantle earthquakes are possibly deviatorial (with the preservation of volume). At such depths, the possible mechanisms of earthquake sources are more similar to earthquake sources generated by advective processes with one expansion pole with isotropic components, which indicates volumet- ric changes in explosive or implosive polarity [Miller et al., 1998].

The nature of mantle earthquakes in the Crimean-Black Sea region differs from the Caucasian region, since the tectonic conditions of their formation are different. According to [Gonchar, 2003], slab wedging occurs not only in vertical, but also in horizontal planes. Which leads to delamination and displacement along different planes. The sharpest boundaries of changes in the physical state of matter in the lithosphere are the boundary of the Moho crust and the boundary of the lithosphere-upper mantle, the bottom of the lithosphere itself. At the base of the lithosphere, there is a sharp change in viscosity properties from the harder and colder lithosphere to the less viscous upper mantle. Therefore, it is most likely that the movement of lithospheric plates occurs along the less viscous layer of the upper mantle. The spatial arrangement of earthquake foci in the Crimean-Black Sea region obtained in [Burmin et al., 2017] illustrates this assumption, because the arrangement of foci repeats the geometry of the lithosphere base topography presented in [Sollogub, 1986].

Conclusion. This article discusses seven specific examples of ambiguous determination of the depth of earthquake hypocenters in the Crimea-Black Sea-Caucasus region. In fact, events that in the catalog are represented as the crust, and after conversion were shown to be the deep mantle, include about 1500 events for the period 1970 to 2015. Of the 1,500 events, 270 events had a depth of over $150 \mathrm{~km}$.

The article shows that those earthquakes, which are listed in the catalog as crustal, do not stand the test solution of the direct problem (calculation of theoretical hodographs) (Fig. 5, $a-11, a$ ) and in fact are mantle, which is confirmed by the solution of the direct problem (Fig. 5, b-11,b).

Moreover, these examples clearly show that the determination of the coordinates of the earthquake hypocenters using algorithms based on the Geiger method does not allow determining the depth of the hypocenters. It was shown in [Burmin, 1992; Burman, Shum- 
lyansky, 2015] that the minimum of functional (1) of the residual times did not guarantee the minimum distance between the real and theoretical focus.

As mentioned above, to determine the coordinates of the hypocenters of the Crimean and Caucasian earthquakes, hodographs were used for depths not exceeding $35 \mathrm{~km}$ for the Crimea, $50 \mathrm{~km}$ for the Caucasus, and 150 for the North Caucasus. This fact is the main reason why deep earthquakes could not be detected.

We want once again to pay attention to the paper of Gobarenko et al. [2016]. The article states that the depths of earthquake foci in the Kerch-Taman zone reach $90 \mathrm{~km}$. That is, the presence of deep earthquakes in the considered region is confirmed by the Crimean seismologists. At the same time, when determining the coordinates of earthquake hypocenters, the authors of the article use a velocity model to depths of $90 \mathrm{~km}$. It can be argued with great probability that if the authors used a velocity model at least up to $300 \mathrm{~km}$, then they would surely get greater depths of foci.

According to the authors, the origin of

\section{References}

Adamia, S., Zakariadze, G., Chkhotua, T., Sadradze, N., Tsereteli, N., Chabukiani, A., \& Gventsadze, A. (2011a). Geology of the Caucasus: a review. Turkish Journal of Earth Sciences, 20, 489-544. https://dx.doi.org/10.3906/yer-100511.

Adamia, S., Alania, V., Chabukiani, A., Kutelia, Z., \& Sadradze, N. (2011b). Great Caucasus (Cavcasioni): a long-lived north-Tethyan Back-arc basin. Turkish Journal of Earth Sciences, 20, 611-628. http://dx.doi.org/10.3906/yer-100512.

Aptikaeva, O. I., Kopnichev, Yu. F., \& Shevchenko, V. I. (1994). The structure of the crust and upper mantle and tectogenesis of the territory of the Garm test site (Tajikistan). Physics of the Earth, (7-8), 53-64 (in Russian).

Blanco, M. J., \& Spakman, W. (1993). The P-wave velocity structure of the mantle below the Iberian Peninsula: evidence for subducted lithosphere below southern Spain. Tectonophysics, mantle earthquakes in the Caucasian and Crimean-Black Sea regions. For the Caucasus region, mantle earthquakes are associated with two reasons: submersion of the lithospheric layer; in the asthenospheric layer, represented in the seismotomographic sections by a low-velocity anomaly, the nature of earthquake foci is associated with fluids formed during phase transition reactions. In the Crimean-Black Sea region, earthquake foci are located in the lithosphere layer, and the sliding of the lithosphere along the less viscous underlying layer of the upper mantle causes tectonic movements in the lithosphere accompanied by earthquakes.

The title of this article contains the question: Mantle earthquakes in the Crimea-Black Sea-Caucasus regions - myth or reality? In our opinion, seven examples from more than a thousand events convincingly show that the existence of deep mantle earthquakes in the Crimea-Black Sea-Caucasus region is not a myth, but an obvious reality.

Acknowledgment. The authors thank T. Yu. Burmina and Jim O'Neill for their help in preparing the manuscript.

221(1), 13-34. https://doi.org/10.1016/00401951(93)90025-F.

Burmin, V. Y. (1992). A new approach to the determination of the parameters of hypocenters of nearby earthquakes. Volcanology and seismology, 3, 73-82 (in Russian).

Burmin, V. Y. (1986). Optimal placement of seismic stations for registration of near earthquakes. Izvestiya. Physicsof the Solid Earth, 22(5), 366371 (in Russian).

Burmin, V. Yu., Shemeleva, I. B., Fleifel, L. D., Avetisyan, A. M., \& Kazaryan, K. S. (2019). Spatial distribution of crustal earthquakes in the Caucasus. Seismic Instruments, 55(1), 84-91 (in Russian).

Burmin, V. Yu., \& Shumlianska, L. A. (2015). Modern seismicity of the Crimea. Questions of engineering seismology, 42(2), 5-16 (in Russian).

Burmin, V. Y., \& Shumlyanskay, L. A. (2018a). On the Problem of Deep Earthquakes in Crimea- 
Black Sea Region. Seismic Instruments, 54(3), 362-371 (in Russian).

Burmin, V. Yu., \& Shumlianska, L. A. (2018b). Spatial distribution of earthquake hypocenters in the Crimea - Black Sea region. Journal of Seismology, 22(2), 391-405. https://doi. org/10.1007/s10950-017-9712-y.

Gabsatarova, I. P. (2010). Deep earthquakes in the Tersko-Sunzha zone. Materials of the fifth international seismological school: "Modern methods of processing and interpretation of seismological data» (pp. 59-64). Vladikavkaz 4-8 October 2010. Obninsk: Publishing house GS RAS (in Russian).

Geiger, L. (1910). Herbsetimmung bei Erdbeben aus den Ankunfzeiten. Nachrichten der K. Gesellschaft der Wissenschaften zu Gottingen, 4, $331-349$.

Geiger, L. (1912). Probability method for the determination of earthquake epicenters from the arrival time only. Bull. St. Louis Univ. 8, 60-71.

Gobarenko, V. S., Murovskaya, A. V., Yegorova, T. P., \& Sheremet, E. E. (2016). Modern collision processes on the northern edge of the Black Sea. Geotectonics, (4), 68-87. https:// doi.org/10.7868/S0016853X16040020 (in Russian).

Godzikovskaya, A. A. (1988). Mantle earthquakes of the Caucasus in the region of the TerskoSunzhensky trough. Physics of the Earth, (7), 102-106 (in Russian).

Godzikovskaya, A. A., \& Reisner, G. I. (1989). Endogenous position of deep earthquakes in the Caucasus. Geotectonics, (3), 15-25 (in Russian).

Gonchar, V. V. (2003). Deformation of the crust of the transition zone Mountain Crimea - Black Sea depression: substantiation of the collisionextrusive setting. Geology and Exploration, (2), 18-25 (in Russian).

Gorbatikov, A. V., Rogozhin, E. A., Stepanova, M. Yu., Kharazova, Yu. V., Andreeva, N. V., Perederin, F. V., Zaalishvili, V. B., Melkov, D. A., Dzeranov, V. V., Dzeboev, B. A., \& Gabaraev, A. F. (2015) Peculiarities of deep structure and modern tectonics of the Greater Caucasus in the Ossetian sector according to a complex of geophysical data. Physics of the Earth, (1), 28-39 (in Russian).
Khain, V. (1975). Structure and main stages in the tectono-magmatic development of the Caucasus: an attempt at geodynamic interpretation. American Journal of Science, 275-A, 131-156.

Kondorskaya, N. V., \& Aranovich, Z. I. (1981). Instruction on the procedure for the production and processing of observations at seismic stations of the ESSN USSR. Moscow: Nauka, $272 \mathrm{p}$. (in Russian).

Koronovsky, N. V. (1997). Main events in the tectonic evolution of the Caucasian segment of the Mediterranean fold belt. Moscow University Bulletin. Ser. geological, (4), 5-12 (in Russian).

Koulakov, I. (2009). LOTOS code for local earthquake tomographic inversion. Benchmarks for testing tomographic algorithms. Bulletin of the Seismological Society of America, 99(1), 194214. http://dx.doi.org/10.1785/0120080013.

Koulakov, I., Zabelina, I., Amanatashvili, I., \& Meskhia, V. (2012). Nature of orogenesis and volcanism in the Caucasus region based on results of regional tomography. Solid Earth, 3(2), 327-337. http://dx.doi.org/10.5194/se-3327-2012.

Kulchitsky, V. E., Safonova, G. P., \& Svidlova, V. A. (1986). Hodographs of seismic waves of the Crimean-Black Sea earthquakes. In Seismological Bulletin of the Western Territorial Zone of the ESSO USSR (Crimea-Carpathians) for 1983 (pp. 94-103). Kiev: Naukova Dumka (in Russian).

Lebedeva, T. M. (1958). Earthquakes in the Caucasus with foci under the earth's crust. Proceedings of the Geological Institute of the Academy of Sciences of the Georgian SSR, (17), 139-159 (in Russian).

Lukk, A. A., \& Shevchenko, V. I. (2019) Seismicity, tectonics and GPS geodynamics of the Caucasus. Izvestiya. Physicsof the Solid Earth, (4), 99-123. https://doi.org/10.31857/S000233372019499123.

McClusky, S., Balassanian, S., Barka, A., Demir, C., Ergintav, S., Georgiev, I., Gurkan, O., Hamburger, M., Hurst, K., Kahle, H., Kastens, K., Kekelidze, G., King, R., Kotzev, V., Lenk, O., Mahmoud, S., Mishin, S, Nadaria, M., Ouzounis, A., Paradissis, D., Peter, Y., Prilepin, M., Reilinger, R., Sanli, I., Seeger, H., Tealeb, A., 
Toksoz, M. N., \& Veis, G. (2000). Global positioning system constraints on plate kinematics and dynamics in the eastern Mediterranean and Caucasus. Journal of Geophysical Research: Solid Earth, 105(B3), 5695-5719. https://doi.org/10.1029/1999JB900351.

Miller, A. D., Foulger, G., Julian, B. R. (1998). NonDouble-Couple Earthquakes 2. Observations. Reviews of Geophysics, 36(4), 551-568. https:// doi.org/10.1029/98RG00717.

Milanovsky, E. E. (1991). Geology of the USSR. Part 3. Moscow: Moscow State University Publishing House, 352 p. (in Russian).

Pustovitenko, B. G., Lushchik, A. V., Boborykina, O. V., Kulchitsky, V. E., Mozhzherina, A. V., Nasonkin, V. A., Pankov, F. N., Porechnova, E. I., Pustovitenko, A. A., Tikhonenkov, E. P., Shvyrlo, N. I. (2014). Monitoring of seismic processes in the Crimean-Black Sea region. Sevastopol: NPC «ECOSI Hydrophysics», 264 p. (in Russian).

Reilinger, R., McClusky, S., Vernant, Ph., Lawrence, Sh., Ergintav, S., Cakmak, R., Ozener, H., Kadirov, F., Guliev, I., Stepanyan, R., Nadariya, M., Hahubia, G., Mahmoud, S. K., ArRajehi, A., Paradissis, D., Al-Aydrus, A., Prilepin, M., Guseva, T., Evren, E., Dmitrotsa, A., Filikov, S. V., Gomez, F., Al-Ghazzi, R., \& Karam, G. (2006). GPS constraints on con- tinental deformation in the Africa-ArabiaEurasia continental collision zone and implications for the dynamics of plate interactions. Journal of Geophysical Research: Solid Earth, 111(B5), B05411. http://dx.doi.org/10.1029/ 2005JB004051.

Rodkin, M. V., Nikitin, A. N., \& Vasin, R. N. (2009). Seismotectonic effects of solid-phase transformations in geomaterials. Moscow: GEOS, 198 p. (in Russian).

Shevchenko, V. I., Lukk, A. A., \& Guseva, T. V. (2017). Autonomous and plate tectonic geodynamics of some mobile belts and structures. Moscow: GEOS, 612 p. (in Russian).

Sollogub, V. B. (1986). Lithosphere of Ukraine. Kiev: Naukova Dumka, 184 p. (in Russian).

Trifonov, V. G., Ivanova, T. P., Bachmanov, D. M. (2012). Evolution of the Central part of the Alpine-Himalayan belt in the Late Cainozoic. Geology and geophysics, 53(3), 289-304 (in Russian).

Zabelina, I., Koulakov, I., Amanatashvili, I., Sami El Khrepy, \& Nassir Al-Arif (2016). Seismic structure of the crust and uppermost mantle beneath Caucasus based on regional earthquake tomography. Journal of Asian Earth Sciences, 119, 87-99. https://doi.org/10.1016/j. jseaes.2016.01.010.

\title{
Мантійні землетруси в регіоні Крим-Чорне море-Кавказ
}

\author{
В. Бурмін ${ }^{1}$, О. Кендзера ${ }^{2}$, А. Шумлянська ${ }^{2}$, Т. Амашукелі ${ }^{2}, 2021$ \\ ${ }^{1}$ Інститут фізики Землі ім. О. Ю. Шмідта, РАН, Москва, Росія \\ ${ }^{2}$ Інститут геофізики ім. С. І. Субботіна НАН України, Київ, Україна
}

Питання про існування вогнищ глибоких землетрусів у регіоні Крим-Чорне море-Кавказ надзвичайно важливе з позиції геодинаміки регіону. Раніше вважали, що в цьому регіоні можуть відбуватися тільки землетруси земної кори. Отримано результати, згідно з якими в регіоні відбуваються землетруси з глибиною принаймні 300 км.

У статті обговорено питання ступеня правдоподібні цих результатів і терміну ix отримання. Розглянуто сім конкретних прикладів неоднозначного визначення глибини гіпоцентрів землетрусів у регіоні. Показано, що визначення координат гіпоцентрів землетрусів за допомогою алгоритмів, заснованих на методі Гейгера, не дає змоги розрахувати глибину гіпоцентру. Описано уявлення авторів про походження мантійних землетрусів у Кавказькому і Кримсько-Чорноморському регіонах. 
Аля Кавказького регіону мантійні землетруси спричиняє занурення літосферного шару; в астеносферному шарі, представленому на сейсмотомографічних розрізах низькошвидкісною аномалією, природа вогнищ землетрусів пов'язана з флюїдами, що утворюються в ході реакцій фазових переходів. У Кримсько-Чорноморському регіоні вогнища землетрусів розміщуються в шарі літосфери; ковзання останньої по менш в'язкому шару верхньої мантії, який залягає нижче, викликає в літосфері тектонічні рухи, що супроводжуються землетрусами. З метою визначення координат гіпоцентрів кримських і кавказьких землетрусів у разі планової обробки використовували годографи для глибин не більш як 35 км (Крим), 50 км (Кавказ) і 150 км (Північний Кавказ). Ця обставина є основною причиною неможливості реєстрації глибоких землетрусів.

Ключові слова: гіпоцентри, землетруси, годографи, сейсмічні хвилі.

\title{
Мантийные землетрясения в регионе Крым-Черное море-Кавказ
}

\author{
В. Бурмин ${ }^{1}$, А. Кендзера ${ }^{2}$, А. Шумлянская ${ }^{2}$, Т. Амашукели ${ }^{2}, 2021$ \\ ${ }^{1}$ Институт физиики Земли им. О. Ю. Шмидта, РАН, Москва, Россия \\ ${ }^{2}$ Институт геофизики им. С. И. Субботина НАН Украины, Киев, Украина
}

Вопрос о существовании очагов глубоких землетрясений в регионе Крым-Черное море-Кавказ чрезвычайно важен с точки зрения геодинамики региона. Ранее считалось, что в данном регионе могут быть только землетрясения земной коры. Получены результаты, согласно которым в регионе происходят землетрясения с глубиной до 300 км.

В статье обсуждается вопрос о степени правдоподобия этих результатов и сроках их получения. Рассмотрены семь примеров неоднозначного определения глубины гипоцентров землетрясений в регионе Показано, что определение координат гипоцентров землетрясений с помощью алгоритмов, основанных на методе Гейгера, не позволяет рассчитать глубину гипоцентров. Описано представление авторов о происхождении мантийных землетрясений в Кавказском и Крымско-Черноморском регионах. Аля Кавказского региона мантийные землетрясения обусловлены погружением литосферного слоя; в астеносферном слое, представленном на сейсмотомографических разрезах низкоскоростной аномалией, природа очагов землетрясений связана с флюидами, образующимися в ходе реакций фазовых переходов. В Крымско-Черноморском регионе очаги землетрясений расположены в слое литосферы; скольжение последней по менее вязкому нижележащему слою верхней мантии вызывает тектонические движения в литосфере, сопровождающиеся землетрясениями. С целью определения координат гипоцентров крымских и кавказских землетрясений при плановой обработке использовались годографы для глубин не более 35 км (Крым), 50 км (Кавказ) и 150 км (Северный Кавказ). Это обстоятельство является основной причиной невозможности регистрации глубоких землетрясений.

Ключевые слова: гипоцентры, землетрясения, годографы, сейсмические волны. 